\section{Michigan Technological \begin{tabular}{lll}
\hline 1 & 8 & University \\
\hline
\end{tabular}}

Michigan Technological University Digital Commons@Michigan Tech

\title{
Hydrometeor-enhanced tephra sedimentation: Constraints from the 18 May 1980 eruption of Mount St. Helens
}

\author{
Adam J. Durant \\ Michigan Technological University \\ William I. Rose \\ Michigan Technological University \\ A. M. Sarna-Wojcicki \\ U.S. Geological Survey \\ S. Carey \\ University of Rhode Island
}

A. C. M. Volentik

University of South Florida

Follow this and additional works at: https://digitalcommons.mtu.edu/geo-fp

Part of the Geology Commons, Mining Engineering Commons, and the Other Engineering Commons

\section{Recommended Citation}

Durant, A. J., Rose, W. I., Sarna-Wojcicki, A. M., Carey, S., \& Volentik, A. C. (2009). Hydrometeor-enhanced tephra sedimentation: Constraints from the 18 May 1980 eruption of Mount St. Helens. Journal of Geophysical Research, 114(B3). http://dx.doi.org/10.1029/2008JB005756

Retrieved from: https://digitalcommons.mtu.edu/geo-fp/24

Follow this and additional works at: https://digitalcommons.mtu.edu/geo-fp

Part of the Geology Commons, Mining Engineering Commons, and the Other Engineering Commons 


\title{
Hydrometeor-enhanced tephra sedimentation: Constraints from the 18 May 1980 eruption of Mount St. Helens
}

\author{
A. J. Durant, ${ }^{1,2,3}$ W. I. Rose, ${ }^{1}$ A. M. Sarna-Wojcicki, ${ }^{4}$ S. Carey, ${ }^{5}$ and A. C. M. Volentik ${ }^{6}$
}

Received 20 April 2008; revised 9 October 2008; accepted 17 December 2008; published 10 March 2009.

[1] Uncertainty remains on the origin of distal mass deposition maxima observed in many recent tephra fall deposits. In this study the link between ash aggregation and the formation of distal mass deposition maxima is investigated through reanalysis of tephra fallout from the Mount St. Helens 18 May 1980 (MSH80) eruption. In addition, we collate all the data needed to model distal ash sedimentation from the MSH80 eruption cloud. Four particle size subpopulations were present in distal fallout with modes at $2.2 \Phi, 4.2 \Phi$, $5.9 \Phi$, and $8.3 \Phi$. Settling rates of the coarsest subpopulation closely matched predicted single-particle terminal fall velocities. Sedimentation of particles $<100 \mu \mathrm{m}$ was greatly enhanced, predominantly through aggregation of a particle subpopulation with modal diameter $5.9 \pm 0.2 \Phi(19 \pm 3 \mu \mathrm{m})$. Mammatus on the MSH80 cloud provided a mechanism to transport very fine ash particles, with predicted atmospheric lifetimes of days to weeks, from the upper troposphere to the surface in a matter of hours. In this mechanism, ash particles initiate ice hydrometeor formation high in the troposphere. Subsequently, the volcanic cloud rapidly subsides as mammatus develop from increased particle loading and cloud base sublimation. Rapid fallout occurs as the cloud passes through the melting level in a process analogous to snowflake aggregation. Aggregates sediment en masse and form the distal mass deposition maxima observed in many recent volcanic ash fall deposits. This work provides a data resource that will facilitate tephra sedimentation modeling and allow model intercomparisons.

Citation: Durant, A. J., W. I. Rose, A. M. Sarna-Wojcicki, S. Carey, and A. C. M. Volentik (2009), Hydrometeor-enhanced tephra sedimentation: Constraints from the 18 May 1980 eruption of Mount St. Helens, J. Geophys. Res., 114, B03204, doi:10.1029/2008JB005756.

\section{Introduction}

[2] Tephra fallout from the 18 May 1980 eruption of Mount St. Helens, Washington (MSH80), produced a regional-scale subaerial ash deposit that featured a distal mass deposition maximum $\sim 325 \mathrm{~km}$ from the volcano [Sarna-Wojcicki et al., 1981; Carey and Sigurdsson, 1982] (Figure 1). Far-range tephra deposits are typically composed of fine ash, which under single-particle gravitational settling, has predicted transport distances of many thousands of kilometers further from the volcano. Carey and Sigurdsson [1982] concluded that particle aggregation rapidly removed fine ash from the atmo-

\footnotetext{
${ }^{1}$ Department of Geological and Mining Engineering and Sciences, Michigan Technological University, Houghton, Michigan, USA.

${ }^{2}$ Department of Earth Sciences, School of Geographical Sciences, University of Bristol, Bristol, UK.

${ }^{3}$ Now at Leverhulme Centre for Human Evolutionary Studies, University of Cambridge, Cambridge, UK.

${ }^{4}$ U.S. Geological Survey, Menlo Park, California, USA.

${ }^{5}$ Graduate School of Oceanography, University of Rhode Island, Narragansett, Rhode Island, USA.

${ }^{6}$ Department of Geology, University of South Florida, Tampa, Florida, USA.
}

Copyright 2009 by the American Geophysical Union. 0148-0227/09/2008JB005756\$09.00 sphere following the MSH80 eruption and was responsible for the "anomalous" downwind thickening. However, the exact aggregate formation mechanism, and how this process impacts the dispersal characteristics of tephra fall deposits, is still not fully understood.

[3] The purpose of this paper is to use understanding gained from study of the Mount St. Helens 1980 eruption to investigate the link between aggregation and distal mass deposition maxima. In addition, we collate all the data needed to model sedimentation from the MSH80 eruption cloud. This standardized resource will facilitate model development and allow intercomparisons between different modeling groups. The paper is structured as follows: In section 2 we present a brief background on the 18 May 1980 Mount St. Helens eruption and distal ash sedimentation and ash aggregation. In section 3 we describe the sampling strategy, analysis techniques used in this study, and particle fall modeling. In section 4 we present a sedimentological analysis of the deposit. In section 5 we discuss the implications of the data for interpretation of volcanic deposits, aggregation and the origin of distal mass deposition maxima, the role of cloud microphysics in particle sedimentation, and propose a conceptual model for distal fallout of volcanic ash and the formation of distal 


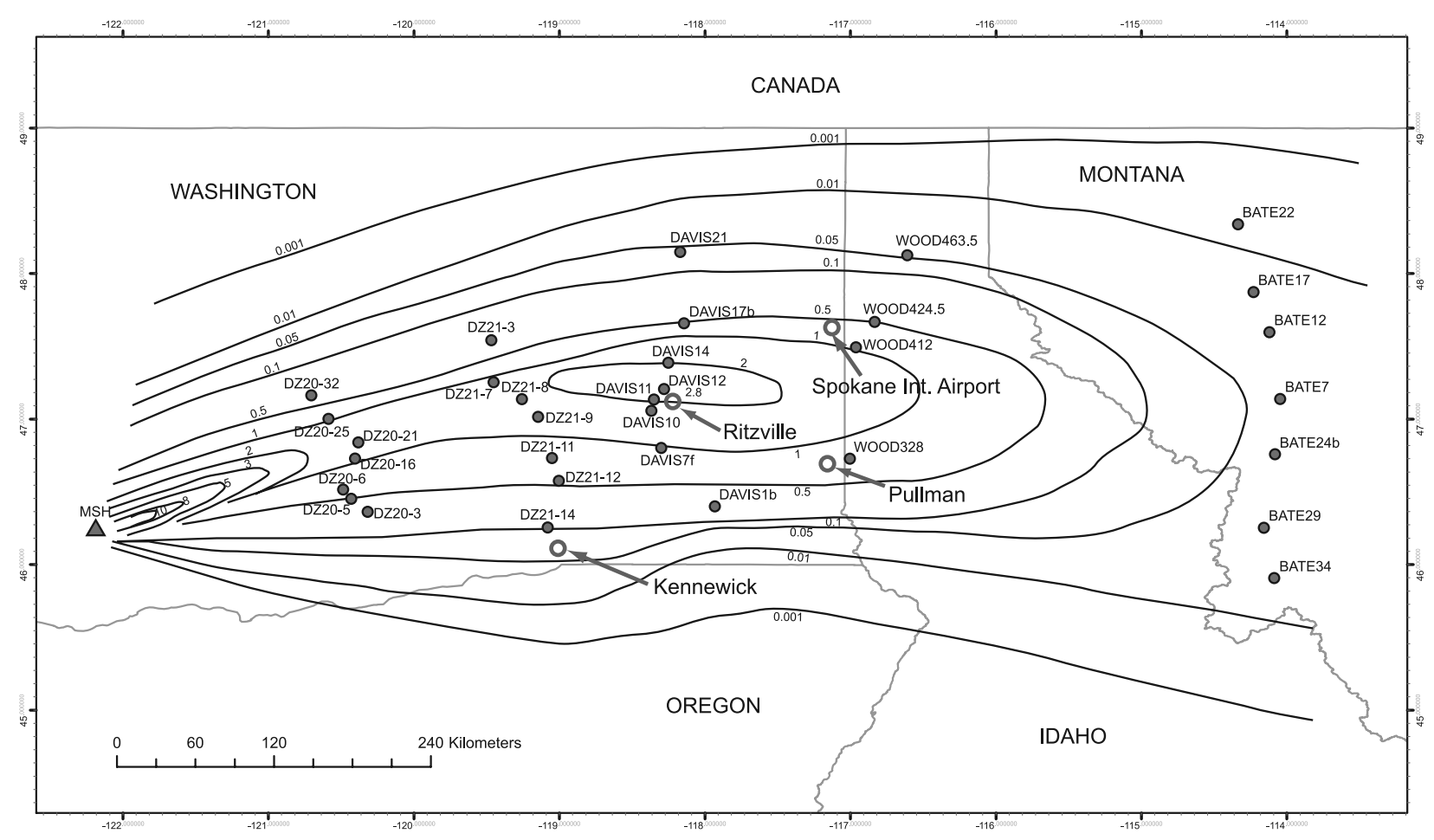

Figure 1. Locations of tephra samples analyzed in this study. The isomass map of Sarna-Wojcicki et al. [1981] is also shown (not exactly to scale). Isomass contours are in $\mathrm{g} \mathrm{cm}^{-2}$.

accumulation maxima. We end with our conclusions in section 6 .

\section{Background}

\subsection{Distal Mass Deposition Maxima and Ash Aggregation}

[4] Satellite remote sensing studies indicate that very fine ash persists in the atmosphere in detectable concentrations for 1-5 days [e.g., Rose et al., 2001; Guo et al., 2004] and can experience regional or global transport prior to deposition [e.g., Fruchter et al., 1980; Rose et al., 2003]. In proximal regions, rapid fallout of large particles generates coarse deposits that thin exponentially with distance from the source volcano [e.g., Pyle, 1989]. The proportion of fine particles and deposit volume are often estimated through extrapolation of proximal thickness-area relation plots [Pyle, 1989; Bonadonna et al., 1998]. However, distal mass deposition maxima are common features of regional-scale tephra deposits, which complicate this relationship and result in an underestimation of fine particle proportion and volume. Historical examples include the 1932 eruption of Quizapu, Chile [Hildreth and Drake, 1992]; the 18 May, 25 May, 12 June, 7 August, and 16-18 October 1980 eruptions of Mount St. Helens [Sarna-Wojcicki et al., 1981]; the 15 June 1991 eruption of Pinatubo (unit II of Wiesner et al. [2004]); the 12-15 August 1991 eruption of Cerro Hudson, Chile [Scasso et al., 1994]; and the 18 August and 16-17 September 1992 eruptions of Mount Spurr, Alaska [McGimsey et al., 2002]. Ash aggregation is linked to the formation of distal deposition maxima and is manifested as a fine particle size subpopulation composite in these deposits that remains relatively uniform with distance [e.g., Carey and Sigurdsson, 1982; Brazier et al., 1983].

\subsection{The 18 May 1980 Mount St. Helens Eruption and Sources of Tephra}

[5] Criswell [1987] distinguishes six phases of the MSH80 eruption in terms of eruptive style and material deposited (Table 1). Phase 1 (0832-0900 LT, where LT = PDT, which is UTC $-7 \mathrm{~h}$ ) included the paroxysmal Plinian eruption and flank collapse, directed blast (a small $\left(0.1 \mathrm{~km}^{3}\right)$ scale, violent pyroclastic flow) and initial column. Two high-altitude coignimbrite plumes from the directed blast reached heights of $\sim 26 \mathrm{~km}$ and $\sim 31 \mathrm{~km}$ within 15 min of the eruption onset, which coincided with an early Plinian column. Phase 2 (0900-1215 LT) included a sustained 14$18 \mathrm{~km}$ high Plinian column dominated by juvenile dacitic material erupted from a shallow magma reservoir [Pallister et al., 1992] and an increase in eruptive intensity at 1100 LT [Sarna-Wojcicki et al., 1981]. Eruption intensity decreased during phase 3 (1215-1500 LT) when explosive events were punctuated by coignimbrite activity. At 1217 PDT, the eruption column changed color from dark to light gray [Criswell, 1987], which marked the eruption of dacitic magma from a deep $(>7 \mathrm{~km})$ magma reservoir [Pallister et al., 1992]. The climactic phase 4 (1500-1715 PDT) was dominated by coignimbrite activity and concluded with a late Plinian phase. By this time, juvenile eruptive products had a silicic andesite composition. During phase 4, airborne particle mass was $7.0 \mathrm{~g} \mathrm{~m}^{-3}$ at $389 \mathrm{~km}$ downwind [Hobbs et al., 1982]. During phase 5 (1715-1815), although explosive activity waned, coignimbrite activity continued. Activity during phase 6 (1815 to 19 May) was minimal and generated a weak ash plume.

[6] Column height varied during each eruptive phase (Table 2) and vertical wind shear generated a complex dispersal pattern [Danielsen, 1981]. The trajectory of the 
Table 1. Eruptive Chronology and Tephra Produced During Each Phase ${ }^{\mathrm{a}}$

\begin{tabular}{|c|c|c|c|c|}
\hline Phase & Time (PDT) & Eruptive Style & Tephra Type & Unit \\
\hline 1 & $0832-0900$ & $\begin{array}{l}\text { paroxysmal: landslide, lateral blast } \\
\text { and associated explosions; } \\
\text { coignimbrite column; } \\
\text { initial magmatic-driven column }\end{array}$ & $\begin{array}{l}\text { cryptodome dacitic pumice; } \\
\text { ash containing accretionary lapilli }\end{array}$ & $\mathrm{t}_{1}, \mathrm{t}_{2},{ }^{\mathrm{b}}$ basal A3, ${ }^{\mathrm{c}}$ unit $1^{\mathrm{d}}$ \\
\hline \multirow[t]{3}{*}{2} & $\begin{array}{l}0900 \\
1010-1035\end{array}$ & $\begin{array}{l}\text { early Plinian sustained column } \\
\text { pyroclastic flow activity }\end{array}$ & dacitic pumice; lithic ash & $\begin{array}{l}\mathrm{t}_{3}{ }^{\mathrm{b}} ; \mathrm{B} 1^{\mathrm{c}, \mathrm{e}} \\
\text { unit } 2^{\mathrm{d}}\end{array}$ \\
\hline & $1035-1100$ & lithic-rich column & white dacitic pumice & \\
\hline & $1100-1215$ & eruption intensity increasing & decreasing lithics & $\mathrm{t}_{5},{ }^{\mathrm{b}} \mathrm{B} 2^{\mathrm{c}, \mathrm{e}}$; unit $3^{\mathrm{d}}$ \\
\hline 3 & $1215-1500$ & $\begin{array}{l}\text { early ash flow: intermittent ash fountains; } \\
\text { coignimbrite input from pyroclastic flows }\end{array}$ & $\begin{array}{l}\text { coignimbrite ash; deep }\left(>7 \mathrm{~km}^{\mathrm{f}}\right) \\
\text { magma reservoir dacitic pumice }\end{array}$ & $\mathrm{t}_{6}, \mathrm{t}_{7}^{\mathrm{b}} ; \mathrm{B} 3^{\mathrm{c}} ;$ unit $3^{\mathrm{d}}$ \\
\hline \multirow[t]{2}{*}{4} & $1500-1625$ & climactic: pyroclastic flow dominated & $\begin{array}{l}\text { silicic andesite white and gray pumice; } \\
\text { PF-derived fine ash; }\end{array}$ & $\mathrm{t}_{7}, \mathrm{t}_{8}, \mathrm{t}_{9} \mathrm{~b}^{\mathrm{b}} ; \mathrm{B} 3^{\mathrm{b}, \mathrm{e}} ;$ unit $3^{\mathrm{d}}$ \\
\hline & $1625-1715$ & late Plinian pulse & $\begin{array}{l}\text { silicic andesite pumice mixed } \\
\text { with coignimbrite ash }\end{array}$ & $\mathrm{t}_{8}, \mathrm{t}_{9}^{\mathrm{b}} ; \mathrm{B} 4, \mathrm{C}^{\mathrm{b}, \mathrm{e}} ;$ unit $3^{\mathrm{d}}$ \\
\hline 5 & $\begin{array}{l}1715-1745 \\
1745-1815\end{array}$ & $\begin{array}{l}\text { late ash flow: eruption waning } \\
\text { small pyroclastic flows }\end{array}$ & coignimbrite ash & $\mathrm{t}_{9}, \mathrm{t}_{10} \mathrm{~b}^{\mathrm{b}} ; \mathrm{C}^{\mathrm{b}} ;$ unit $3^{\mathrm{d}}$ \\
\hline 6 & 1815 to 19 May & posteruption: weak ash-rich plume & coignimbrite ash; residual fallout & $\mathrm{t}_{10}{ }^{\mathrm{b}} ; \mathrm{D}^{\mathrm{b}} ;$ unit $3^{\mathrm{d}}$ \\
\hline $\begin{array}{l}{ }^{\mathrm{a}} \text { Ad } \\
{ }^{\mathrm{b}} \text { Pro } \\
{ }^{\mathrm{c}} \text { Pro } \\
{ }^{\mathrm{d}} \text { Dis } \\
{ }^{\mathrm{e}} \text { Car } \\
{ }^{\mathrm{e}} \text { Pall }\end{array}$ & $\begin{array}{l}\text { d from Criswell }[ \\
\text { al unit terminolog } \\
\text { al unit terminolog } \\
\text { unit terminology o } \\
\text { et al. }[1990] \text {. } \\
\text { ret al. }[1992] \text {. }\end{array}$ & $\begin{array}{l}\text { 7]. } \\
\text { f Criswell [1987]. } \\
\text { f Waitt and Dzurisin [1981]. } \\
\text { arna-Wojcicki et al. }[1981] \text {. }\end{array}$ & & \\
\hline
\end{tabular}

MSH80 cloud was monitored by aircraft [e.g., Danielsen, 1981; Hobbs et al., 1982], spaceborne meteorological instruments including GOES and AVHRR [Sarna-Wojcicki et al., 1981; Sparks et al., 1986; Holasek and Self, 1995], a pair of USAF satellites [Rice, 1981; Moore and Rice, 1984; Sparks et al., 1986] and by National Weather Service (NWS) radars stationed at Portland, Oregon, and Spokane and Auburn, Washington [Harris et al., 1981]. Radiosonde soundings were taken 3 times daily at 0500, 1100 and 1700 PDT (UTC - $7 \mathrm{~h}$ ) at Spokane International Airport (GEG).

[7] There were four compositionally distinct sources of fine particles generated during the MSH80 eruption: (1) lithicrich material from the initial collapse and directed blast; (2) cryptodome magma [Hoblitt and Harmon, 1993]; (3) shallow conduit-resident magma; and (4) $>7 \mathrm{~km}$ deep magma [Pallister et al., 1992]. Coignimbrite activity combined and modified material from these sources. Pyroclastic flows in the initial directed blast and predominantly in the afternoon of 18 May (phases 3 and 4) may have generated most of the fine particulates $(<50 \mu \mathrm{m}$ diameter) injected into the atmosphere [Carey et al., 1990] from elutriation [e.g., Dartevelle et al., 2002] (especially glass-rich fines [Walker, 1972]) and particle comminution (milling) [e.g., Bonadonna et al., 2002; Horwell et al., 2003].

\subsection{MSH80 Distal Ash Fall Characteristics and Chronology}

[8] Ash fall occurred at distances up to and $>1000 \mathrm{~km}$ from the volcano (Table 3). Distal MSH80 ash fall consisted of three units, although only a single light gray ash layer was distinguishable as far downwind as Montana [SarnaWojcicki et al., 1981]: (1) unit 1 (corresponding to the proximal A3 unit of Waitt and Dzurisin [1981]) consisted of dark dacitic fine ash derived in part from the initial directed blast, which was $1 \mathrm{~mm}$ thick $130 \mathrm{~km}$ from the volcano; (2) unit 2 (corresponding to the proximal B1 unit) consisted of a pumice-poor lithic ash erupted between 0900 and 1035 PDT and was not detected at distances beyond 200$250 \mathrm{~km}$; and (3) unit 3 (corresponding to proximal B2 and
Table 2. Plume Height as Observed by Radar and GOES Visible and IR Imagery ${ }^{\mathrm{a}}$

\begin{tabular}{|c|c|}
\hline Time (PDT) & Height $(\mathrm{km})$ \\
\hline \multicolumn{2}{|c|}{ Radar } \\
\hline 0832:44 & 3.11 \\
\hline 0845:16 & 24.02 \\
\hline 0849:12 & 24.00 \\
\hline 0900:00 & 16.51 \\
\hline 1000:00 & 13.60 \\
\hline 1100:00 & 15.24 \\
\hline 1130:00 & 16.15 \\
\hline $1200: 00$ & 17.41 \\
\hline $1230: 00$ & 17.41 \\
\hline $1300: 00$ & 13.47 \\
\hline 1330:00 & 14.60 \\
\hline 1400:00 & 14.61 \\
\hline $1500: 00$ & 14.65 \\
\hline 1600:00 & 15.84 \\
\hline 1700:00 & 19.23 \\
\hline 1800:00 & 7.98 \\
\hline 1900:00 & 6.13 \\
\hline 2000:00 & 4.89 \\
\hline 2100:00 & 4.94 \\
\hline 2200:00 & 4.99 \\
\hline \multicolumn{2}{|c|}{ GOES } \\
\hline 0850:00 & 26.12 \\
\hline 0920:00 & 30.75 \\
\hline 0950:00 & 25.90 \\
\hline $1020: 00$ & 20.93 \\
\hline 1050:00 & 15.67 \\
\hline $1120: 00$ & 15.21 \\
\hline $1150: 00$ & 15.65 \\
\hline $1220: 00$ & 19.21 \\
\hline $1250: 00$ & 16.37 \\
\hline 1320:00 & 16.39 \\
\hline $1350: 00$ & 15.47 \\
\hline 1420:00 & 15.67 \\
\hline $1450: 00$ & 17.37 \\
\hline $1520: 00$ & 16.33 \\
\hline 1550:00 & 16.47 \\
\hline 1620:00 & 19.10 \\
\hline $1650: 00$ & 16.84 \\
\hline
\end{tabular}

${ }^{\text {a}}$ Radar digitized from Harris et al. [1981] and GOES visible and IR imagery from Holasek and Self [1995]. 
Table 3. Ash Fall Chronology for the 18 May 1980 Eruption of Mount St. Helens, Washington ${ }^{\text {a }}$

\begin{tabular}{|c|c|c|c|c|c|c|c|c|c|}
\hline \multirow{2}{*}{\multicolumn{2}{|c|}{ Time (LT) }} & \multirow[b]{3}{*}{ Location } & \multicolumn{5}{|c|}{ NAD83/WGS84 } & \multirow[b]{3}{*}{ Description } & \multirow[b]{3}{*}{ Reference } \\
\hline & & & \multicolumn{3}{|c|}{ UTM } & \multirow[b]{2}{*}{ Latitude N } & \multirow[b]{2}{*}{ Longitude W } & & \\
\hline Start & End & & Zone & $\mathrm{E}$ & $\mathrm{N}$ & & & & \\
\hline 0950 & 1100 & Yakima, Washington & 10 & 690994 & 5163964 & 46.6021 & 120.5062 & Ash cloud overhead & A \\
\hline 1000 & & Tampico, Washington & 10 & 663543 & 5155726 & 46.5352 & 120.8672 & $\begin{array}{l}\text { Ash fall; } 30 \mathrm{~km} \mathrm{WSW} \\
\text { of Yakima }\end{array}$ & A \\
\hline 1215 & & Spokane, Washington & 10 & 476470 & 5281604 & 47.6874 & 117.3135 & $\begin{array}{l}\text { Sun halo appeared; } \\
\text { diffuse cloud front } \\
\text { from satellite }\end{array}$ & B \\
\hline 1400 & & Spokane, Washington & 10 & 476470 & 5281604 & 47.6874 & 117.3135 & $\begin{array}{l}\text { Ash cloud visible overhead } \\
\text { from ground observer }\end{array}$ & B \\
\hline 1543 & & Spokane, Washington & 10 & 476470 & 5281604 & 47.6874 & 117.3135 & Ash began falling at Spokane & B \\
\hline 1400 & 1615 & Pullman, Washington & 11 & 486353 & 5175112 & 46.7314 & 117.1786 & Dark ash fall & $\mathrm{B}, \mathrm{C}$ \\
\hline 1615 & 0200 & Pullman, Washington & 11 & 486353 & 5175112 & 46.7314 & 117.1786 & Light colored ash fall & $\mathrm{B}, \mathrm{C}$ \\
\hline $2000-2030$ & & Missoula, Montana & 12 & 271843 & 5195309 & 46.8722 & 113.9940 & $\begin{array}{l}\text { Ash fall began on south } \\
\text { end of Missoula transect }\end{array}$ & B \\
\hline $2100-2200$ & & Rose Crossing, Montana & 11 & 697416 & 5357643 & 48.3411 & 114.3358 & $\begin{array}{l}\text { Ash fall began on north } \\
\text { end of Missoula transect }\end{array}$ & B \\
\hline
\end{tabular}

${ }^{a}$ References are A, Harris et al. [1981, p. 331]; B, Sarna-Wojcicki et al. [1981, p. 587]; and C, Hooper et al. [1980].

B4 units) consisted of pale brown pumice-rich ash erupted between 1035 and 1715. Carey and Sigurdsson [1982] presented an analysis of deposit component abundances as a function of distance from Mount St. Helens (Table 4).

[9] Much of the transport occurred in the jet stream at a height of about $11.5 \mathrm{~km}$ (based on radiosonde soundings) where wind speed was $\sim 30 \mathrm{~m} \mathrm{~s}^{-1}\left(\sim 108 \mathrm{~km} \mathrm{~h}^{-1}\right)$. Ash generated from the initial blast and Plinian phases (phase 1 of Criswell [1987]) was dispersed by high-velocity winds at the level of the tropopause to the east and was dark toned in GOES visible imagery [Holasek and Self, 1995]. The MSH80 cloud became lighter from 1220 to 1520 (during phase 2 of Criswell [1987]), which probably resulted from a higher fraction of glass-rich fines in the coignimbrite plumes. A strong Plinian column developed at $\sim 1625$ LT and subsequent GOES imagery of the cloud showed a transition to darker tones.

[10] The arrival of the cloud front typically preceded ash fall at the ground by $1-3 \mathrm{~h}$ (Table 3). Dark ash first fell at Pullman ( 390 km from Mount St. Helens) at 1400 and then at 1615 LT the ash color lightened [Hooper et al., 1980]. The light ash fall must correspond to the latter part of phase 2 in which the eruption transitioned to pyroclastic flow-dominated activity and coignimbrite input to the column. Transport time from Mount St. Helens to Spokane ( $\sim 400 \mathrm{~km}$ from Mount St. Helens) in the jet stream was $\sim 3 \mathrm{~h} 40 \mathrm{~min}$, where the arrival of the cloud front preceded ash fall by $1 \mathrm{~h} 43 \mathrm{~min}$. It follows that bulk ash in the cloud settled at an average fall velocity of $\sim 1.5 \mathrm{~m} \mathrm{~s}^{-1}$.

[11] A distal mass deposition maximum centered on Ritzville, Washington, $300 \mathrm{~km}$ from Mount St. Helens (Figure 1), was attributed to aggregation-enhanced sedimentation [Carey and Sigurdsson, 1982]. In the same region, mammatus lobes were observed on the base of the volcanic cloud (Figure 2). The distal mass deposition maximum resulted from an increase in deposition of unit 3 , though there was also indication that unit 1 thickened $\sim 400-500 \mathrm{~km}$ from the volcano. Fallout of loosely bound small $(0.25-0.5 \mathrm{~mm})$ clusters composed of ash particles $<40 \mu \mathrm{m}$ was observed in distal regions, e.g., at Pullman, Washington, $390 \mathrm{~km}$ to the ENE [Sorem, 1982], and at Kennewick, Washington, $\sim 190 \mathrm{~km}$ to the east [Rose et al., 1982] (Figure 1). Through numerical modeling, Carey and
Sigurdsson [1982] inferred that ash particles $<63 \mu \mathrm{m}$ were incorporated in MSH80 aggregates. Armienti et al. [1988] determined that particles $<30 \mu \mathrm{m}$ must have aggregated to reproduce the deposit dispersal pattern. Occasional large (hundreds of microns) pumice ash particles were carried hundreds of kilometers from the volcano [Sorem, 1982; Schumacher, 1994]. Aggregates falling in proximal regions were generally composed of liquid water, whereas aggregates reaching the ground at distal locations were loosely bound and showed no evidence of water binding. These morphological differences imply that different aggregation processes occurred in the column and drifting stratospheric cloud regions.

\section{Methods}

\subsection{MSH80 Distal Ash Sampling Strategy and Original Field Data}

[12] The distal ash layer from the 18 May 1980 eruption of Mount St. Helens was the most extensively sampled deposit from a recent historic stratospheric eruption. This

Table 4. Deposit Component Analysis From Carey and Sigurdsson [1982]

\begin{tabular}{cccccc}
\hline $\begin{array}{c}\text { Particle Size } \\
\text { Fraction } \phi\end{array}$ & $\begin{array}{c}\text { Pumice/Glass } \\
\text { (wt \%) }\end{array}$ & $\begin{array}{c}\text { Feldspar } \\
\text { (wt \%) }\end{array}$ & $\begin{array}{c}\text { Lithics } \\
\text { (wt \%) }\end{array}$ & $\begin{array}{c}\text { Mafics } \\
\text { (wt \%) }\end{array}$ & $\begin{array}{c}\text { Total } \\
\text { (wt \%) }\end{array}$ \\
\hline-3.5 & 100.0 & 0.0 & 0.0 & 0.0 & 100.0 \\
-3.0 & 100.0 & 0.0 & 0.0 & 0.0 & 100.0 \\
-2.5 & 100.0 & 0.0 & 0.0 & 0.0 & 100.0 \\
-2.0 & 92.7 & 0.0 & 7.3 & 0.0 & 100.0 \\
-1.5 & 66.4 & 0.0 & 33.6 & 0.0 & 100.0 \\
-1.0 & 37.1 & 0.0 & 62.9 & 0.0 & 100.0 \\
-0.5 & 24.9 & 0.0 & 75.1 & 0.0 & 100.0 \\
0.0 & 44.7 & 3.8 & 51.5 & 0.0 & 100.0 \\
0.5 & 35.0 & 14.2 & 49.6 & 1.2 & 100.0 \\
1.0 & 10.3 & 42.3 & 42.0 & 5.4 & 100.0 \\
1.5 & 8.7 & 56.5 & 26.6 & 8.2 & 100.0 \\
2.0 & 13.1 & 52.7 & 19.1 & 15.1 & 100.0 \\
2.5 & 14.7 & 47.9 & 14.4 & 23.1 & 100.0 \\
3.0 & 24.1 & 40.5 & 12.8 & 22.6 & 100.0 \\
3.5 & 28.9 & 39.1 & 10.9 & 21.1 & 100.0 \\
4.0 & 32.8 & 40.3 & 9.8 & 17.2 & 100.0 \\
4.5 & 50.9 & 30.0 & 7.3 & 11.8 & 100.0 \\
5.0 & 65.2 & 22.9 & 8.3 & 3.6 & 100.0 \\
5.5 & 68.1 & 21.5 & 8.0 & 2.4 & 100.0 \\
\hline
\end{tabular}




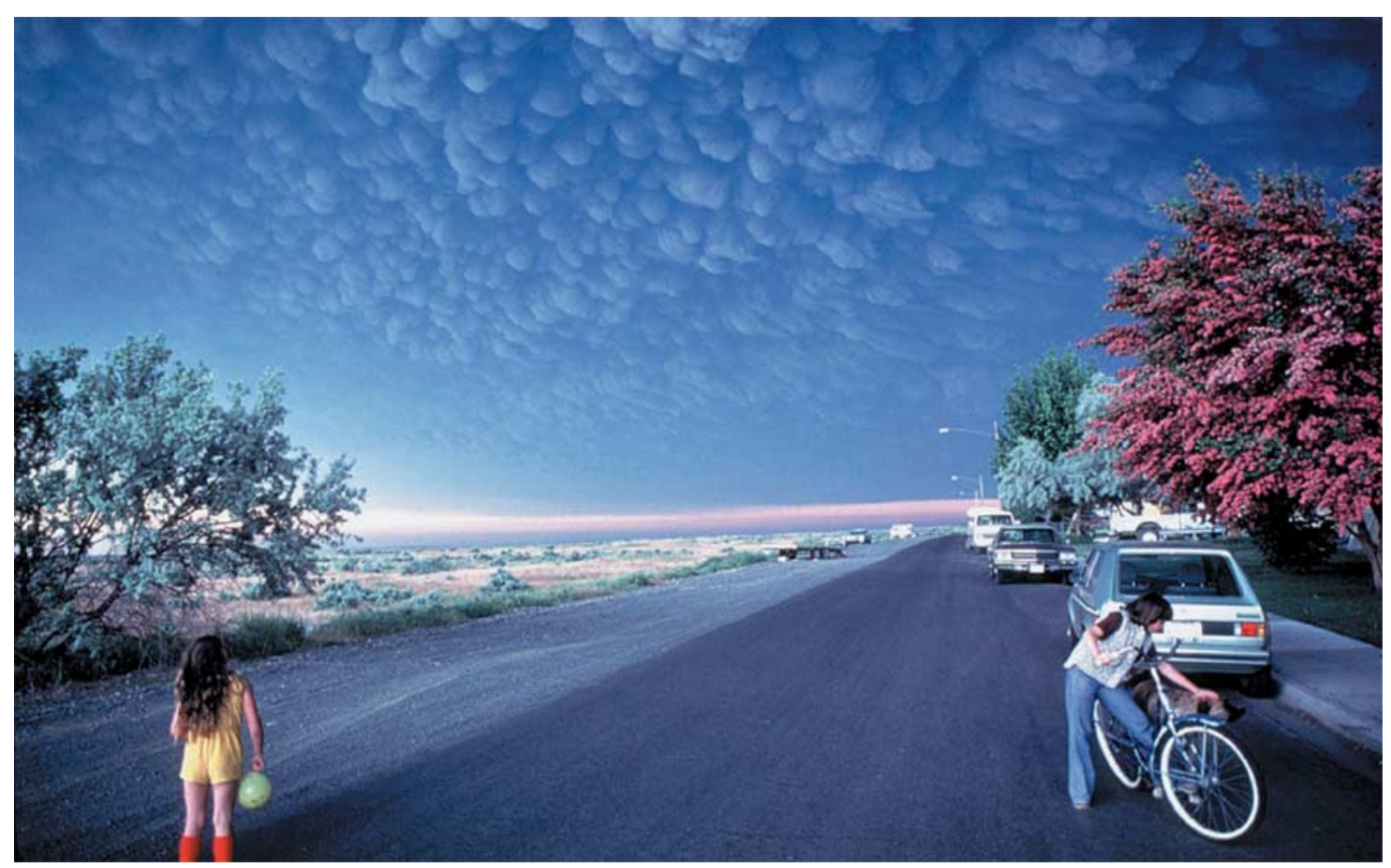

Figure 2. Mammatus lobes on the Mount St. Helens volcanic cloud viewed from Ephrata, Washington, on 18 May 1980 (copyright D. Miller).

was in part because fallout produced a regionally dispersed subaerial deposit and the resources were available to support a prompt sampling effort. A team of U.S. Geological Survey (USGS) scientists, coordinated by A. SarnaWojcicki, carried out a series of transects running roughly perpendicular to the dispersal axis of the ash fall deposit up to $\sim 630 \mathrm{~km}$ from the volcano (Table 5). Investigators collected samples and measured mass per unit area and bulk density. Most transects were completed between 19 and 21 May 1980 before rainfall modified the deposit. A more detailed study of the proximal stratigraphy was carried out after this time by several investigators. The final transect was completed on 22 May 1980, in part after a small amount of modification by rainfall.

[13] In this study, original field maps and samples were retrieved from the USGS Menlo Park Tephrochronology Laboratory archive. Maps were scanned to generate digital copies and splits were prepared from ash samples collected during the May 1980 field campaign. Original field notebooks were also consulted, where available. As this study predated handheld GPS units, all information on sampling locations resides on the original field maps, which in most cases were road maps. Coordinates of sample locations (Figure 1) were determined with high precision using a Web-based GIS tool (http://www.topozone.com/). Ash deposit thicknesses at each location were recovered from the original field maps.

\subsection{Particle Size Analysis}

[14] In this study, MSH80 distal tephra deposit particle size was measured using a Malvern Instruments Mastersizer 2000 in the Physical Geography Laboratories, University of Cambridge. Laser diffraction particle size analysis (LDPSA) offers a rapid, accurate and reproducible method to measure the size of volcanic ash particles through the range 0.1$2000 \mu \mathrm{m}$ (see ISO 13320), although the submicron size characterization may be subject to some measurement uncertainty from shape effects. Particle size (volume-based) is inferred through inversion of observed scattering with model-predicted scattering, using, e.g., Lorenz-Mie scattering theory [e.g.,

Table 5. MSH80 Tephra Deposit Sampling Transects Carried Out by the USGS

\begin{tabular}{|c|c|c|}
\hline Date & Transect & Investigator \\
\hline 24 June 1980 & Burnt Peak (Washington) to Greenhorn Buttes (Washington) & A. Sarna-Wojcicki \\
\hline 19-21 May 1980 & Tower Rock (Washington) to Green Mountain (Washington) & Richard Waitt \\
\hline 19-21 May 1980 & Packwood (Washington) to Hamilton Buttes (Washington) & Richard Waitt \\
\hline 20 May 1980 & Swauk Prairie (Washington) to Kusshi Creek (Washington) & Dan Dzurisin \\
\hline Summer 1980 & Rock Island Dam (Washington) to Vernita Bridge (Washington) & W. Hays \\
\hline Summer 1980 & Ephrata (Washington) to Mesa West (Washington) & W. Hays \\
\hline 21 May 1980 & Sims Corner (Washington) to Glade (Washington) & Dan Dzurisin \\
\hline $21-22$ May 1980 & Tucannon (Washington) to Louie Creek (Washington) & Jonathan Davis \\
\hline 21 May 1980 & White Bird (Idaho) to Libby (Montana) & Spencer Wood \\
\hline 19-21 May 1980 & Rose Crossing (Montana) to Butte South (Montana) & Tom Bateridge \\
\hline
\end{tabular}


Bohren and Huffman, 1983], in which light scattering angle is inversely proportional to particle size and scattering intensity is proportional to particle volume. For our analyses, we assumed an ash refractive index of 1.6 and absorptivity of 0.1 , and each size measurement is an average of three size distribution measurements each acquired over $20 \mathrm{~s}$.

[15] Particle size distributions measured at a given location are subject to the history of magma fragmentation and subsequent transport [Wohletz et al., 1989]. Volcanic ash subpopulations result from (1) fragmentation mechanisms; (2) variation in particle characteristics; and (3) size-dependent transport mechanisms. Polymodal analysis of MSH80 samples was performed using the KWare Geological Software SFT application (http://www.ees1.lanl.gov/Wohletz/ SFT.htm) to identify subpopulation modes, dispersion and proportions. The algorithm was used to fit and optimize a series of lognormal subpopulations to the measured size distribution until the residual between the model and measurement was $<5 \%$.

\subsection{Particle Shape Variation}

[16] Particle shape was characterized using a Malvern Instruments PharmaVision 830 at the University of South Florida to perform 2-D quantitative shape analysis [Bonadonna et al., 2006; Volentik et al., 2006]. During each analysis, the instrument images 100,000 s of individual particles then quantifies 2-D particle size and shape using automated image analysis. Particle shape is described in terms of roundness and convexity. Roundness is a dimensionless particle length-width relationship described by $4 \pi A / L^{2}$, where $L$ is particle perimeter and $A$ is the projected particle area (a perfect circle has a value of 1 and a needle has a value close to 0$)$. Convexity is a dimensionless parameter calculated from $A /(A+B)$, where $A$ is the true particle area and $B$ is the area enclosed by the convex perimeter (a convex morphology has a value of 1 and a concave morphology has a value close to 0 ). Particle shape in 3-D is highly complex and these 2-D parameters provide only an approximate measure of shape.

\subsection{Particle Fall Modeling}

[17] Particles falling through the atmosphere accelerate downward due to gravity until an equilibrium state between drag force and buoyancy is reached, and the particle falls at the terminal fall velocity, $V_{t}$. Bonadonna et al. [1998] present an analytical solution for finding the terminal velocity of particles falling through the atmosphere as a function of particle size and particle Reynolds number $R e_{p}$, based on an earlier analysis by Kunii and Levenspiel [1969]. James et al. [2002] follow an empirical approach for modeling particle fall based on an analysis by Clift et al. [1978]. Brown and Lawler [2003] present a correlation for sphere terminal settling velocity, based on a reanalysis of empirical studies carried out in the twentieth century. Uncertainty in terminal velocity measurements is caused by drag influence from the wall of the vessel used to perform the experiments, the so-called "wall effect," which tends to retard sphere settling, especially at low particle $R e_{p}$. Brown and Lawler apply a correction to account for this effect, and derive a correlation for the drag coefficient and terminal fall velocity for all particle Reynolds numbers $<2 \times 10^{5}$, and a highly accurate correlation for Reynolds numbers $<4000$.
[18] To determine terminal fall velocity for particle Reynolds numbers $<4000$ (which covers the volcanic ash size fraction), dimensionless sphere diameter $d^{*}$ is first calculated as [Brown and Lawler, 2003, equation 25]

$$
d_{*}=d_{p}\left[\frac{g \rho_{f}\left(\rho_{p}-\rho_{f}\right)}{\mu^{2}}\right]^{1 / 3},
$$

where $d_{p}$ is particle diameter, $g$ is gravity, $\rho_{f}$ is fluid density, $\rho_{p}$ is particle density, and $\mu$ is absolute fluid viscosity $\left(\mathrm{kg} \mathrm{m}^{-1} \mathrm{~s}^{-1}\right)$. Atmospheric density $\rho_{f}$ is calculated from the ideal gas law [Rogers and Yau, 1989, p. 29]:

$$
\rho_{f}=\frac{p}{R T},
$$

where $p$ is ambient pressure, $R$ is the gas constant for dry air $\left(287 \mathrm{~J} \mathrm{~kg}^{-1} \mathrm{~K}^{-1}\right)$, and $T$ is ambient temperature. Atmospheric dynamic viscosity can be approximated by [Rogers and Yau, 1989, p. 102]

$$
\mu(T)=1.72 \times 10^{-5}\left(\frac{392}{T+120}\right)\left(\frac{T}{273}\right)^{3 / 2} .
$$

Then, for $d^{*}<190\left(R e_{p}<4000\right)$, dimensionless settling velocity $u^{*}$ may be calculated as [Brown and Lawler, 2003, equation 37]

$$
u_{*}=\frac{d_{*}^{2}\left(22.5+d_{*}^{2.046}\right)}{0.0258 d_{*}^{4.046}+2.81 d_{*}^{3.046}+18 d_{*}^{2.046}+405} .
$$

Finally, particle terminal settling velocity is related to dimensionless settling velocity by [Brown and Lawler, 2003, equation 24]

$$
u_{t}=\frac{u_{*}}{\left[\rho_{f}^{2} / g \mu\left(\rho_{p}-\rho_{f}\right)\right]^{1 / 3}} .
$$

Terminal fall velocities were calculated for single spherical particles with size spanning the range of measured particle size in the MSH80 deposit to provide a minimum estimate of single-particle settling rates. Atmospheric conditions constrained by the sounding at Spokane International Airport (GEG) at 1100 PDT (1800 UTC) on 18 May 1980. In all calculations the atmosphere was divided into a series of horizontal layers and terminal fall velocity and total fall time were calculated in each level for a range of particle sizes with densities of $600 \mathrm{~kg} \mathrm{~m}^{-3}$ (pumice), $1000 \mathrm{~kg} \mathrm{~m}^{-3}$ (ice), and $2300 \mathrm{~kg} \mathrm{~m}^{-3}$ (glass). Integrated horizontal transport distance, a measure of the lateral transport distance that particles would be expected to experience, was calculated from particle terminal settling rates and horizontal wind speed measured in each layer by the radiosonde.

\section{Results}

[19] All data reported here are available in the auxiliary material. $^{1}$

\footnotetext{
${ }^{1}$ Auxiliary material data sets are available at $\mathrm{ftp}: / / \mathrm{ftp}$.agu.org/apend/jb/ 2008jb005756. Other auxiliary material files are in the HTML.
} 
GEOMETRIC
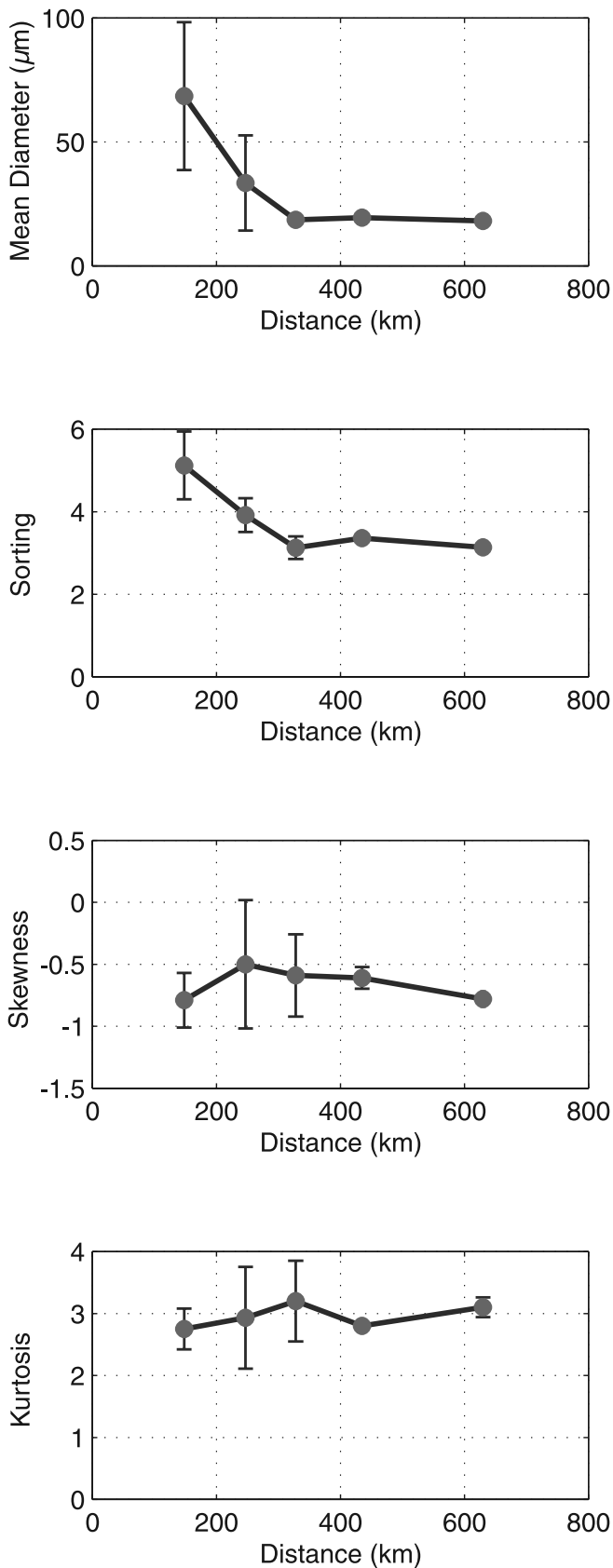

LOGARITHMIC
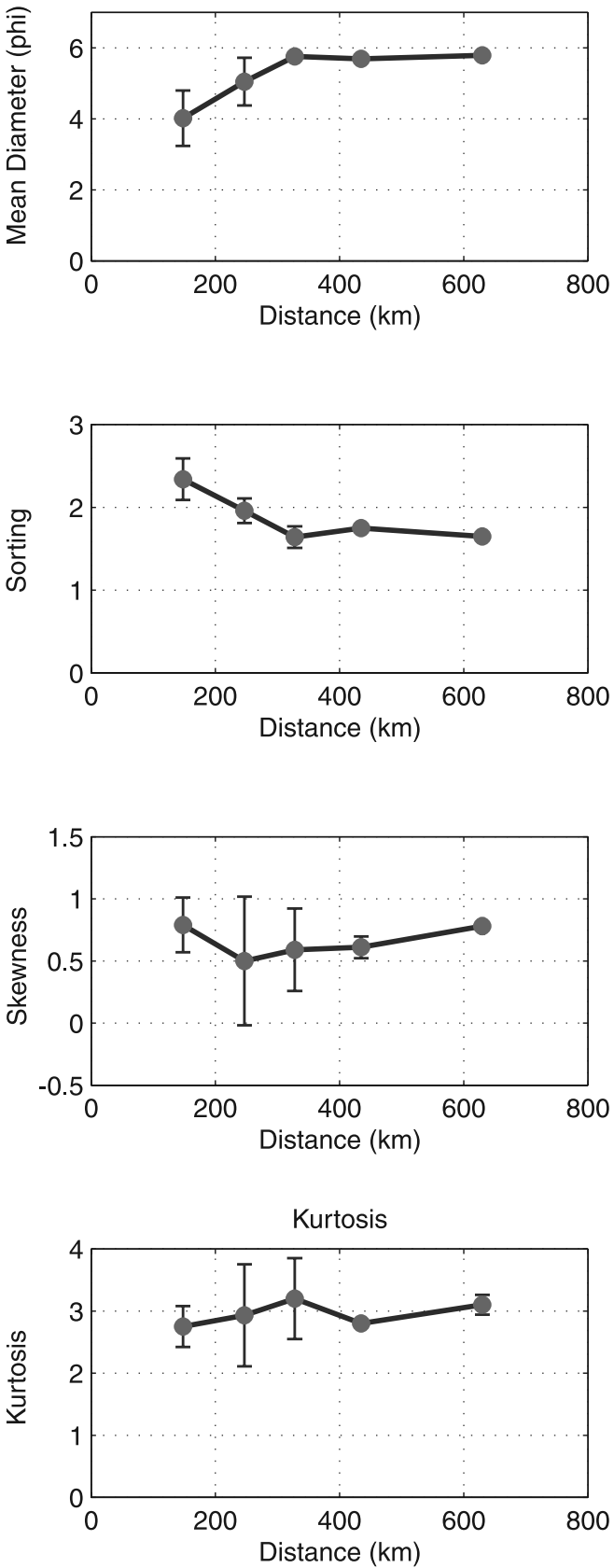

Figure 3. Sedimentology of MSH80 tephra fall as a function of distance from the volcano. Mean values and standard deviation were calculated for samples collected along a given transect for particle size, sorting, skewness, and kurtosis.

\subsection{Size Characteristics of Distal $(>130 \mathrm{~km})$ Fallout}

[20] Bulk sedimentological parameters, including mean particle size, sorting, skewness, and kurtosis were calculated for each sample (Figure 3 and Table 6). Mean particle size of bulk fallout averaged by transect decreased from $4.0 \Phi$ $(68.5 \mu \mathrm{m})$ at $148 \mathrm{~km}$ (Dzurisin-20 transect) to $5.8 \Phi(19 \mu \mathrm{m})$ at $328 \mathrm{~km}$ (Davis transect). At $330 \mathrm{~km}$ from the volcano, bulk fallout consisted of $>90 \mathrm{wt} \%$ particles $<88 \mu \mathrm{m}$ on average and $>60$ wt $\%<31 \mu \mathrm{m}$. Mean particle size and sorting of fallout beyond $330 \mathrm{~km}$ remained fixed and invariant (within standard deviation, $\sigma$ ). Furthermore, variation in all other parameters (shown by the $1 \sigma$ error bar) converged to zero at distances beyond $\sim 330 \mathrm{~km}$. This suggests that particles with a wide range of sizes were sedimenting en masse.

[21] The majority of coarse particles $<3 \Phi(>125 \mu \mathrm{m})$ fell out within $330 \mathrm{~km}$ of the volcano (Figures $4 \mathrm{a}-4 \mathrm{c}$ ), proportions of fine particles between 4 and $7 \Phi(7.81-62.5 \mu \mathrm{m})$ increased with distance (Figures $4 \mathrm{e}-4 \mathrm{~g}$ ), and proportions of very fine particles $>7 \Phi(<7.81 \mu \mathrm{m})$ remained fairly constant with distance from the volcano (Figures $4 \mathrm{~h}-4 \mathrm{j}$ ). In more detail, particles in the size fraction $0-1 \Phi(500-1000 \mu \mathrm{m})$ mostly settled from the cloud within $200 \mathrm{~km}$ of the volcano (Figure $4 \mathrm{a}$ ). The proportion of size fraction $1-2 \Phi$ 
Table 6. Average Sedimentological Characteristics of MSH80 Fallout Calculated Using the Method of Moments ${ }^{\mathrm{a}}$

\begin{tabular}{|c|c|c|c|c|c|c|c|c|c|c|}
\hline & \multicolumn{2}{|c|}{ DZ20 } & \multicolumn{2}{|c|}{ DZ21 } & \multicolumn{2}{|c|}{ Davis } & \multicolumn{2}{|c|}{ Wood } & \multicolumn{2}{|c|}{ Bate } \\
\hline & Mean & $\sigma$ & Mean & $\sigma$ & Mean & $\sigma$ & Mean & $\sigma$ & Mean & $\sigma$ \\
\hline \multicolumn{11}{|c|}{ Geometric $(\mu \mathrm{m})$} \\
\hline Mean & 68.5 & 29.8 & 33.5 & 19.2 & 18.6 & 2.2 & 19.5 & 2.0 & 18.2 & 2.2 \\
\hline Sorting & 5.1 & 0.8 & 3.9 & 0.4 & 3.1 & 0.3 & 3.4 & 0.1 & 3.1 & 0.2 \\
\hline Skewness & -0.8 & 0.2 & -0.5 & 0.5 & -0.6 & 0.3 & -0.6 & 0.1 & -0.8 & 0.1 \\
\hline Kurtosis & 2.8 & 0.3 & 2.9 & 0.8 & 3.2 & 0.7 & 2.8 & 0.1 & 3.1 & 0.2 \\
\hline \multicolumn{11}{|c|}{ Logarithmic $(\Phi)$} \\
\hline Mean & 4.0 & 0.8 & 5.1 & 0.7 & 5.8 & 0.2 & 5.7 & 0.1 & 5.8 & 0.2 \\
\hline Sorting & 2.3 & 0.2 & 2.0 & 0.1 & 1.6 & 0.1 & 1.7 & 0.0 & 1.6 & 0.1 \\
\hline Skewness & 0.8 & 0.2 & 0.5 & 0.5 & 0.6 & 0.3 & 0.6 & 0.1 & 0.8 & 0.1 \\
\hline Kurtosis & 2.8 & 0.3 & 2.9 & 0.8 & 3.2 & 0.7 & 2.8 & 0.1 & 3.1 & 0.2 \\
\hline
\end{tabular}

${ }^{\mathrm{a}}$ See Blott and Pye [2001].
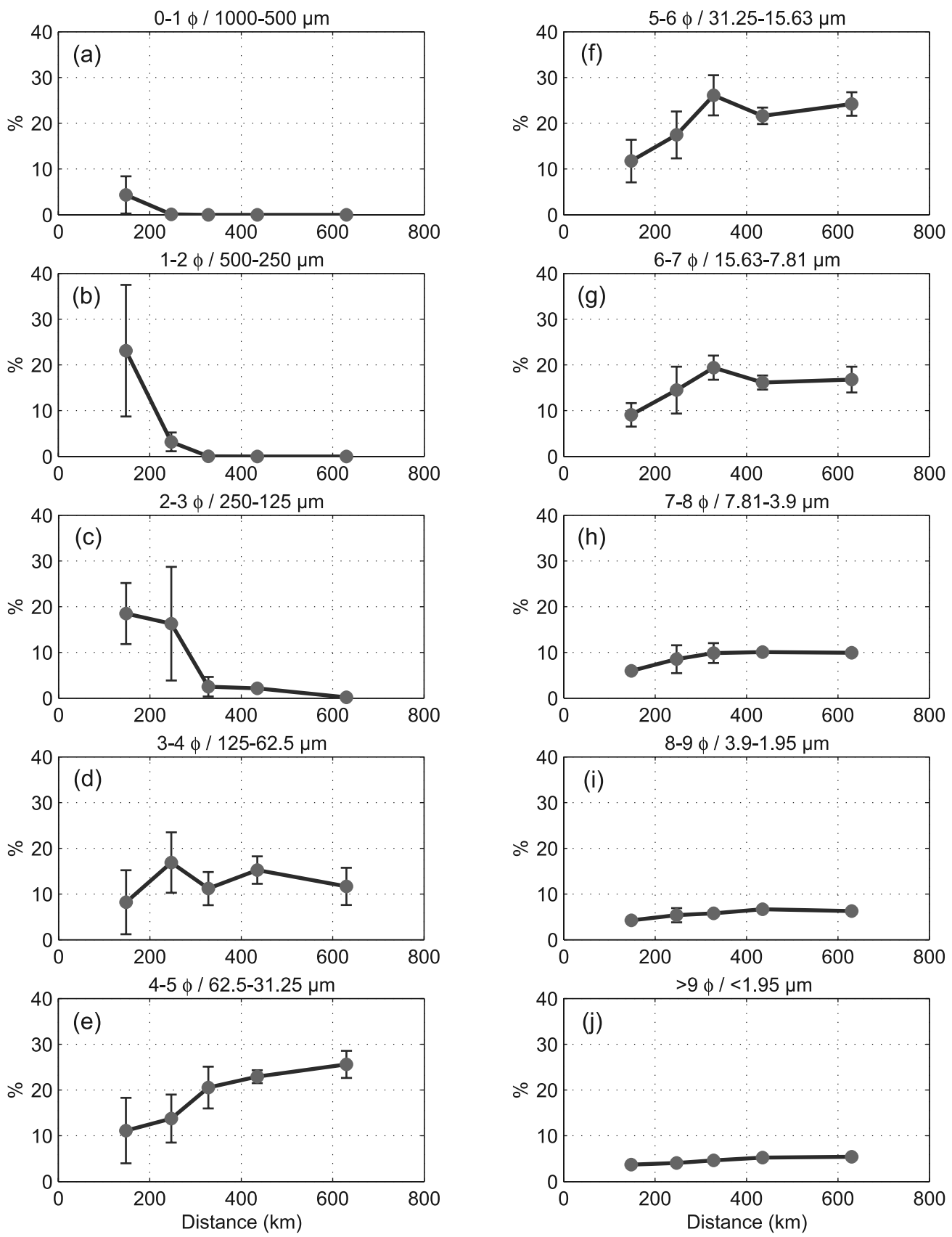

Figure 4. Proportions of ash particles from 0 to $>9 \Phi$ averaged by transect and as a function of distance from the volcano. 

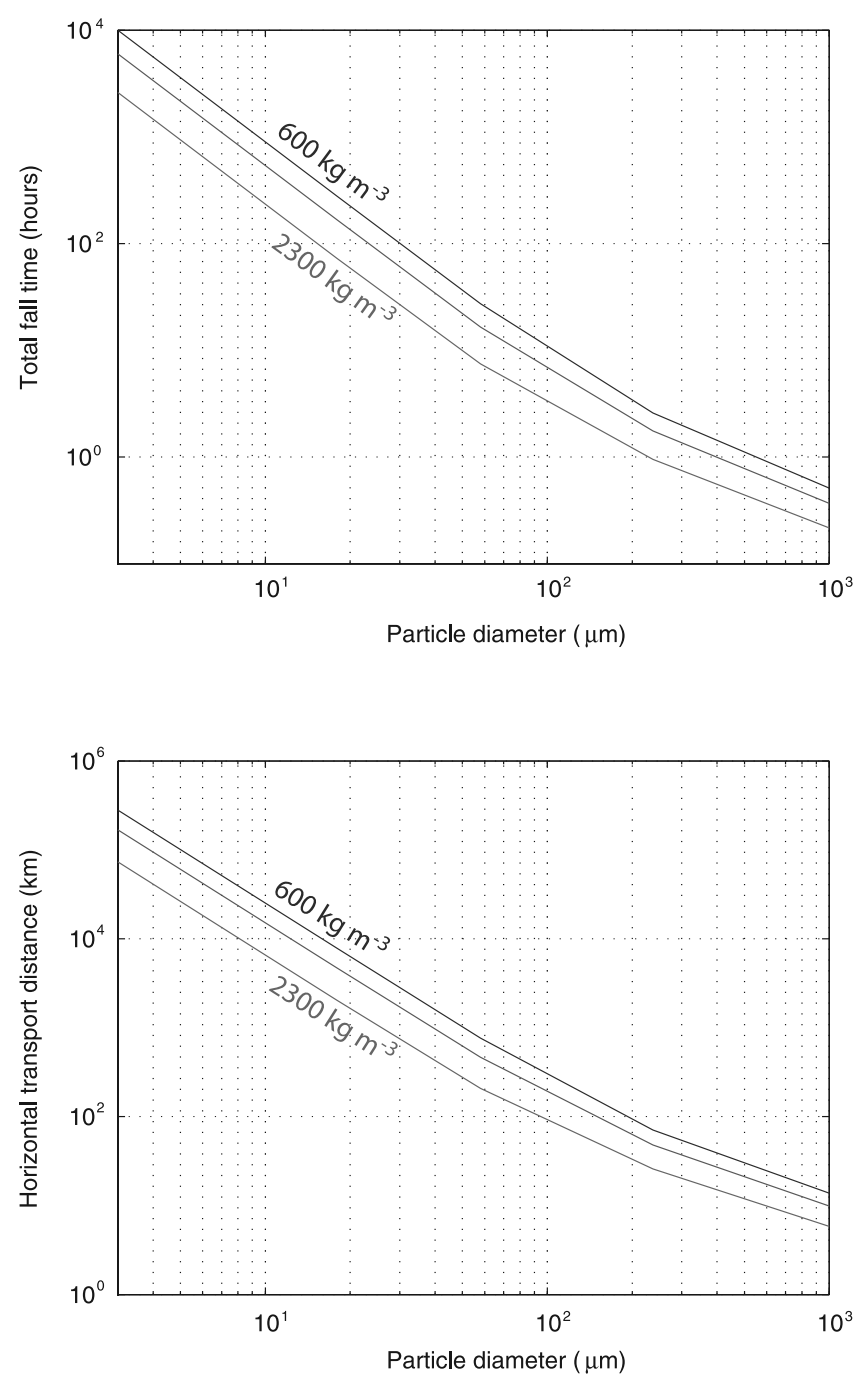

Figure 5. Particle terminal fall velocities for spherical particles with density of 600,1000 , and $2300 \mathrm{~kg} \mathrm{~m}^{-3}$ calculated as a function of height in the atmosphere. Particle sizes correspond to subpopulation modes. Constraints on atmospheric conditions were taken from the sounding at Spokane International Airport (GEG) on 18 May 1980 at 1100 PDT (1800 UTC).

(250-500 $\mu \mathrm{m}$ ) decreased rapidly within $260 \mathrm{~km}$ (Figure 4b). Spherical particles $>200 \mu$ m diameter settling from $11.5 \mathrm{~km}$ have predicted transport distances of $<100 \mathrm{~km}$ (Figure 5) and it is inferred that these coarse particles were deposited as single particles through gravitational settling, which results in a decreasing deposit mean particle size with distance from the volcano (Figure 3).

[22] The proportion of size fraction $2-3 \Phi(125-250 \mu \mathrm{m})$ ranged from $\sim 16-18.5 \mathrm{wt} \%$ in both the DZ-20 and DZ-21 transects and decreased to $\sim 2-2.5 \mathrm{wt} \%$ at $330-430 \mathrm{~km}$ distance (Figure 4c). The proportion of size fraction 3-4 $\Phi$ $(62.5-125 \mu \mathrm{m})$ fluctuated around an average value of $12.7 \mathrm{wt}$ $\%$ at most distances (Figure $4 \mathrm{~d}$ ). The proportion of size fraction $4-5 \Phi(31.25-62.5 \mu \mathrm{m})$ increased from $11.1 \mathrm{wt} \%$ at $148 \mathrm{~km}$ to $25.6 \mathrm{wt} \%$ at $630 \mathrm{~km}$ (Figure $4 \mathrm{e}$ ). The proportion of particles in size fraction $5-7 \Phi(7.81-31.25 \mu \mathrm{m})$ reached a maximum at $330 \mathrm{~km}$ from the volcano in the region of the secondary maximum in mass deposition (Figures $4 \mathrm{f}$ and $4 \mathrm{~g}$ ). The proportion of size fraction 7-8 $\Phi(3.9-7.81 \mu \mathrm{m})$ increased before leveling out at $\sim 10 \mathrm{wt} \%$ at $630 \mathrm{~km}$ (Figure 4h). The proportions of size fraction 8-9 $\Phi(1.95-$ $3.9 \mu \mathrm{m})$ and $>9 \Phi(<1.95 \mu \mathrm{m})$ remained fairly constant with distance and had an average abundance of $5.66 \mathrm{wt} \%$ and $4.6 \mathrm{wt} \%$ respectively (Figures $4 \mathrm{i}$ and $4 \mathrm{j}$ ). The mean particle size of ash samples in the Davis transect which traversed the mass deposition maximum was $\sim 19 \mu \mathrm{m}$ (Table 6). Spherical particles with diameter $<19 \mu \mathrm{m}$ and density $2300 \mathrm{~kg} \mathrm{~m}^{-3}$ have predicted total fall times $>72 \mathrm{~h}$ and transport distances $>2000 \mathrm{~km}$ (Figure 5), and accounting for form drag would increase this distance [Walker, 1971; Wilson and Huang, 1979; Suzuki, 1983; Dellino et al., 2005]. Fallout times of single particles were considerably longer than the observed total fall time of $\sim 4 \mathrm{~h}$ so, clearly, fine particles $<100 \mu \mathrm{m}$ in the MSH80 cloud were settling at a rate far greater than singleparticle terminal velocities (as suggested previously by Carey and Sigurdsson [1982]).

[23] There are 4 particle size subpopulations in the MSH80 distal tephra (Figures 6-11 and Tables 7 and 8) with average modes at $2.2 \Phi / 233 \mu \mathrm{m}$ (subpopulation 1), $4.2 \Phi / 58 \mu \mathrm{m}$ (subpopulation 2), $5.9 \Phi / 19 \mu \mathrm{m}$ (subpopulation 3), $8.3 \Phi / 3 \mu \mathrm{m}$ (subpopulation 4). Fallout $<260 \mathrm{~km}$ from the volcano (DZ20 and DZ21 transects) had four subpopulations and fallout $>260 \mathrm{~km}$ from the volcano had three subpopulations. The coarse subpopulation 1 fined and decreased in abundance with distance, and was not found at distances $>260 \mathrm{~km}$ (beyond DZ21 transect) (Figures 7 and 11). The proportion of subpopulation 3 reached a maximum of $66 \mathrm{wt} \%$ at $330 \mathrm{~km}$ (Figure 11), which corresponded to the location of the Ritzville distal mass deposition maximum, observations of mammatus clouds and ash aggregate fall.

[24] In summary, the proportion of subpopulation 3 reached a maximum at $330 \mathrm{~km}$ (Figure 11) which corresponds to the location of the distal mass deposition maximum and observations of ash aggregate fall. Furthermore, in bulk MSH80 fallout, the proportion of size fraction 7.81-31.25 $\mu \mathrm{m}$ $(5-7 \Phi)$ and subpopulation 3 increased over the mass deposition maximum (Figure 5). From these observations it is inferred that MSH80 ash aggregates were composed of a particle subpopulation with a mode at $\sim 19 \mu \mathrm{m}$. Aggregates may also include "oversized" particles of $100 \mathrm{~s} \mu \mathrm{m}$ diameter [Sorem, 1982], but these tend to have highly irregular morphologies and low density (e.g., pumice particles).

\subsection{Particle Shape Variation}

[25] Bulk average convexity over the entire distal deposit was $0.91 \pm 0.03$ and roundness was $0.62 \pm 0.02$. For comparison, ash particle roundness in 3 compositionally distinct eruptions ranged from 0.6 to 0.9 (Fuego, Guatemala, on 14 October 1974; Crater Peak, Alaska, on 18 August 1992; and the Ash Hollow Member, Ogallala Formation, between 9 and $11 \mathrm{Ma}$ [ [Riley et al., 2003]. Smaller particles in the MSH80 deposit tended to be less rounded and more concave (Figure 12). There was a higher occurrence of more convex and less rounded particles over the region of the distal mass deposition maximum (300-450 km from source) (Figure 13).

[26] The MSH80 cloud became crystal-enriched over time [Rose et al., 1983], which suggests glass particles 


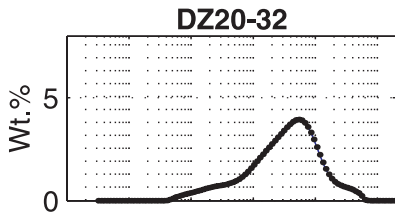

DZ20-25

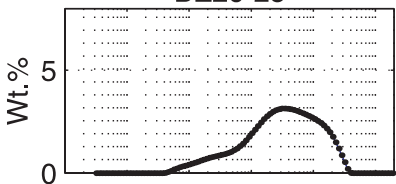

DZ20-21

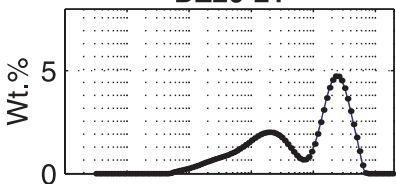

DZ20-16

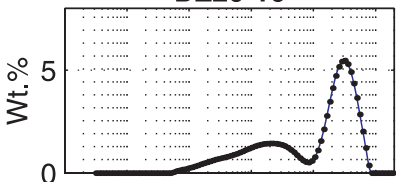

DZ20-6

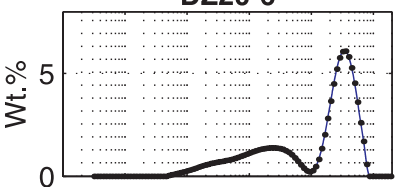

DZ20-5

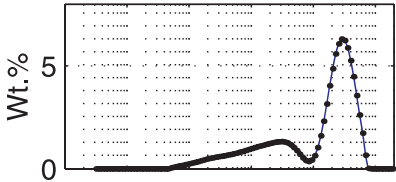

DZ20-3

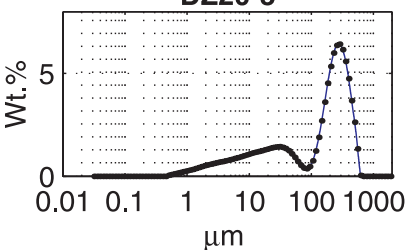

DZ20-32

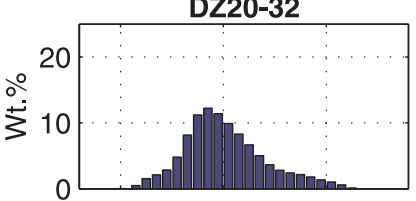

DZ20-25

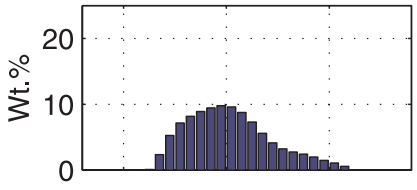

DZ20-21

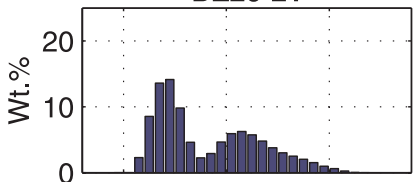

DZ20-16

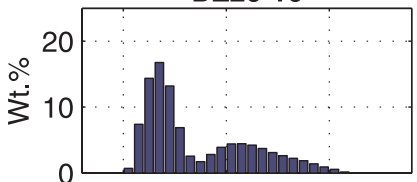

DZ20-6

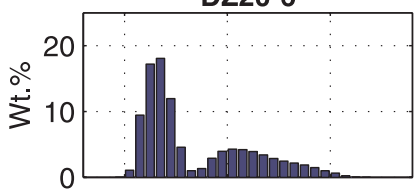

DZ20-5

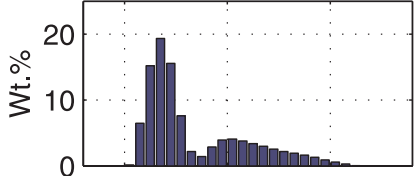

DZ20-3

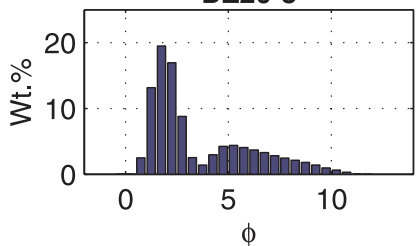

DZ20-32

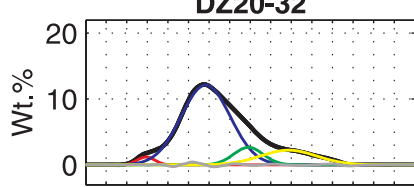

DZ20-25

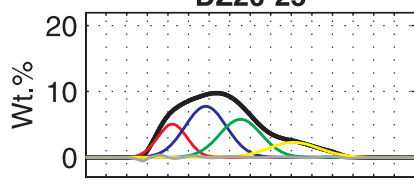

DZ20-21

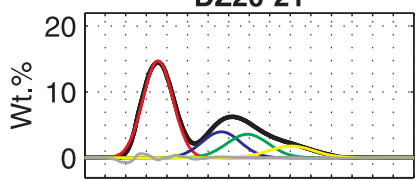

DZ20-16

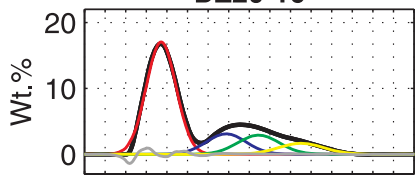

DZ20-6

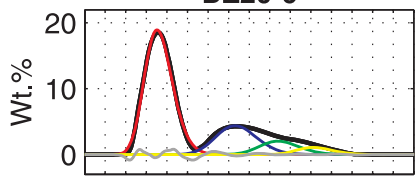

DZ20-5

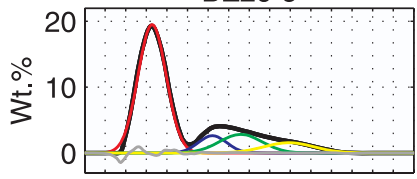

DZ20-3

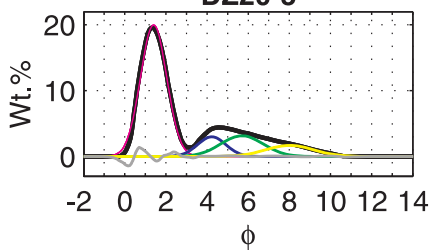

Figure 6. Particle size distributions of samples in DZ20 transect. Size distribution is shown in units of (left) $\mu \mathrm{m}$ and (middle) phi. (right) Lognormal subpopulations.

were preferentially involved in aggregation and removed earlier. For example, at Missoula, Washington, the glass component accounted for 82 wt $\%$ of fallout, while the average magmatic glass percentage was only $\sim 64 \%$ [Rose et al., 1983]. The higher occurrence of more convex and less rounded particles over the region of the distal mass deposition maximum may reflect a preference for inclusion of glassy particles with highly irregular morphologies and large surface area to volume ratios into ash aggregates [Rose and Hoffman, 1980; Rose et al., 1983].

\section{Discussion}

\subsection{Water-Initiated Aggregation in the MSH80} Volcanic Cloud

[27] Uncertainty remains on the nature of the aggregation mechanism, though it is established that the dominant aggregation mechanism is controlled by the amount of water present, and the phase and size of hydrometeors in the cloud [e.g., Sparks et al., 1997]. Laboratory measurements indicate that volcanic ash particles nucleate ice in supercooled liquid water drops at approximately $-20 \pm 5^{\circ} \mathrm{C}$ [Durant and Shaw, 2005; Shaw et al., 2005] and volcanic clouds emplaced in the upper troposphere/stratosphere contain frozen hydrometeors [e.g., Rose et al., 2004]. In the initial hours of the eruption, before significant fallout of fine ash occurred, the MSH80 volcanic cloud contained significant water. Water vapor mass estimates range from $3.1 \times$ $10^{9} \mathrm{~kg}$ [Murcray et al., 1981] to $3.1 \times 10^{10} \mathrm{~kg}$ [Durant, 2007] from magmatic sources alone, and water vapor flux to the atmosphere during the eruption exceeded the proportion of very fine ash $(<1-66 \mu \mathrm{m})$ by a factor of $\sim 8$ [Hobbs et al., 1982]. Ice nucleation in the high-level drifting cloud would have been rapid due to an abundance of ash particles 


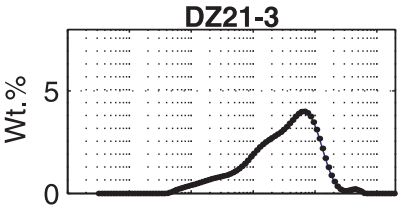

DZ21-7

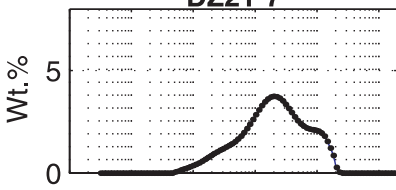

DZ21-8

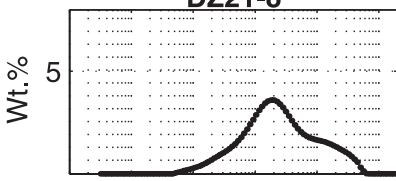

DZ21-9

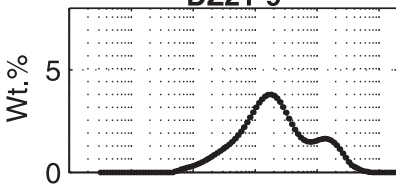

DZ21-11

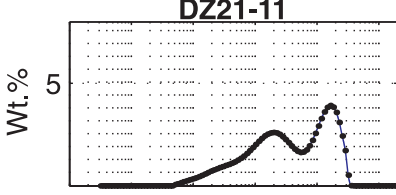

DZ21-12

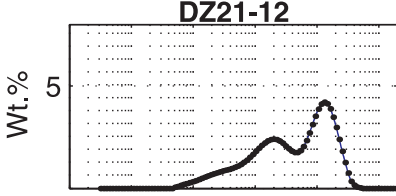

DZ21-14

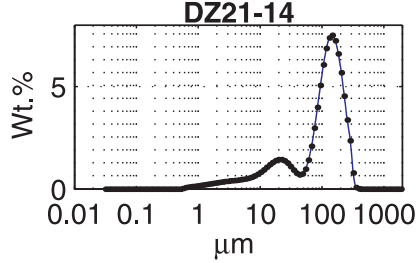

DZ21-3

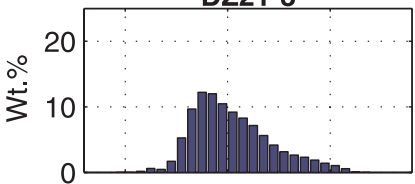

DZ21-7

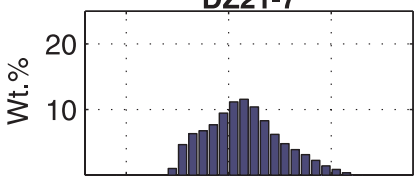

DZ21-8

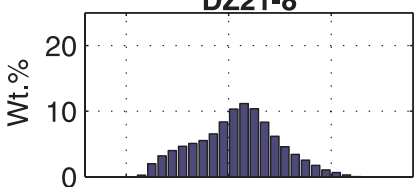

DZ21-9

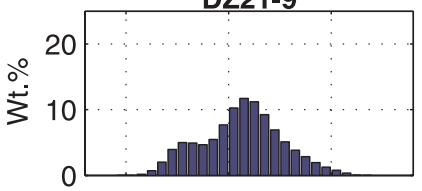

DZ21-11

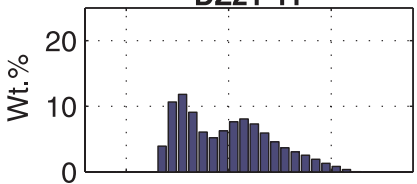

DZ21-12

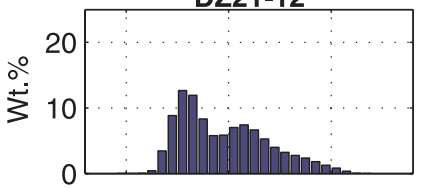

DZ21-14

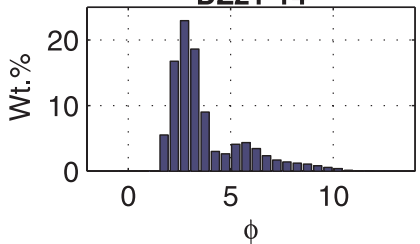

DZ21-3

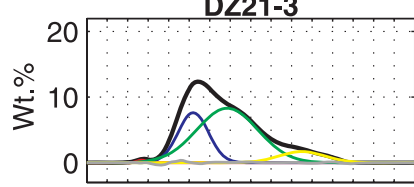

DZ21-7

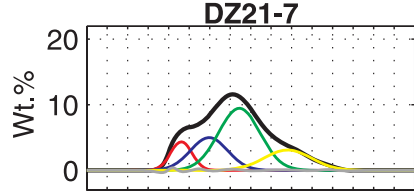

DZ21-8

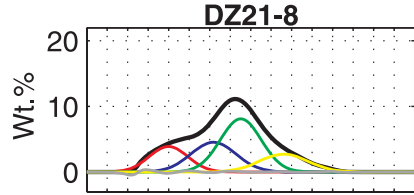

DZ21-9

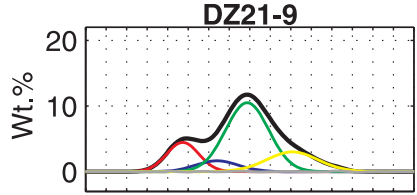

DZ21-11

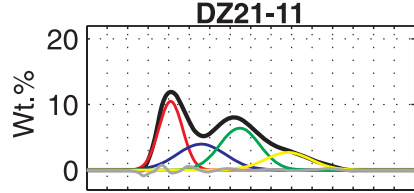

DZ21-12
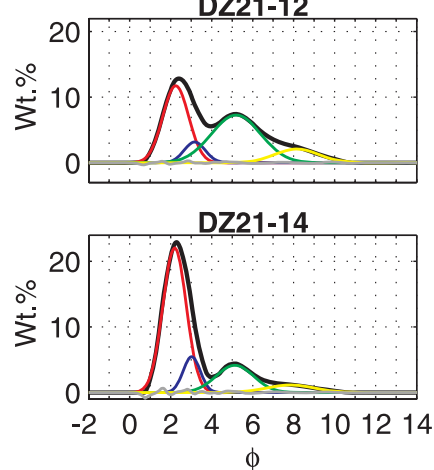

Figure 7. Particle size distributions of samples in DZ21 transect. Size distribution is shown in units of (left) $\mu \mathrm{m}$ and (middle) phi. (right) Lognormal subpopulations.

to act as ice nuclei, and subsequent ice crystal growth would occur through deposition directly from the vapor phase, as in cirrus clouds.

[28] Electrostatic particle attraction has been proposed as a primary binding mechanism for particles in the MSH80 cloud [Sorem, 1982]. Electrostatic charging in volcanic plumes results from magma fragmentation and particle collisions (triboelectric charging) [Gilbert et al., 1991; James et al., 2000, 2002; Miura et al., 2002; James et al., 2003; Mather and Harrison, 2006], and collisions of mixed phase particles (ice crystals, graupel and supercooled liquid water droplets, and ash particles) [Mather and Harrison, 2006], in which charge transfer is dependent on liquid water content (LWC) and temperature [Williams, 1995]. In a volcanic cloud, mixed phase particle populations can exist in the eruption column during rise (condensation and freezing), but also during sedimentation as the cloud passes though the $0^{\circ} \mathrm{C}$ melting level. Electrostatic particle aggregation is a balance between gravitational and electrostatic attraction (e.g., the ratio of gravitational to electrostatic forces exceeds unity at separation distances of $100 \mu \mathrm{m}$ for a $10 \mu \mathrm{m}$ diameter particle [Sparks et al., 1997]), so electrostatic attraction will be less effective at low particle concentrations. There are very few measurements of particle number concentrations in volcanic clouds, which hinders a quantitative evaluation of thresholds of particle concentrations and particle separation distances for electrostatic aggregation.

[29] There are, however, several lines of evidence that support the presence of early ice and other types of hydrometeors (raindrops, graupel/hailstones and snow) in volcanic clouds, and a link between ash-hydrometeor formation 


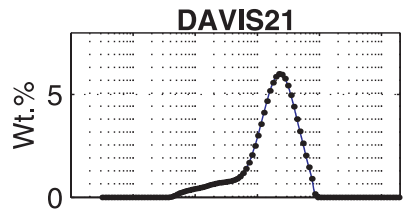

DAVIS17b

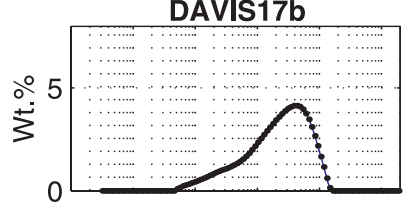

DAVIS14

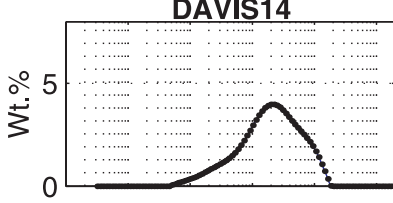

DAVIS12

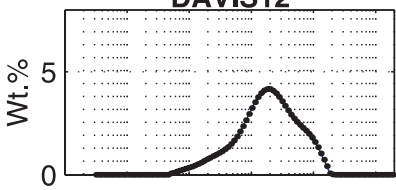

DAVIS11

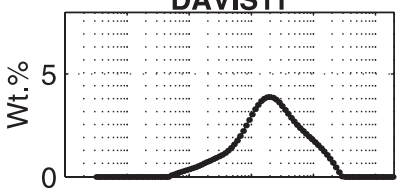

DAVIS10

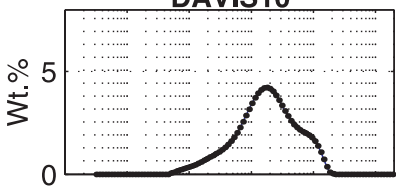

DAVIS7f

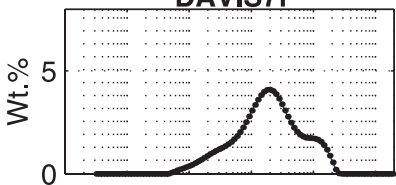

DAVIS1b

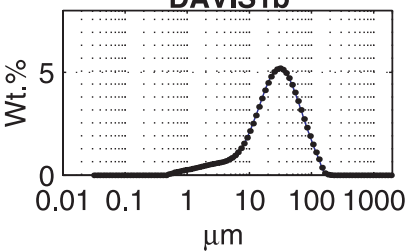

DAVIS21
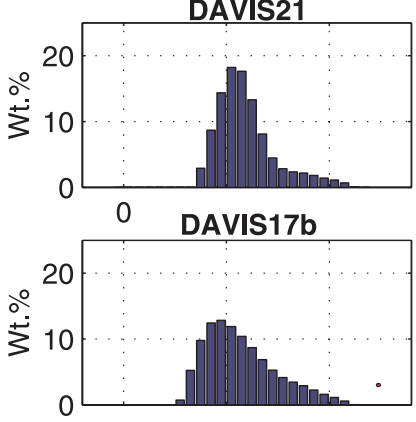

DAVIS14

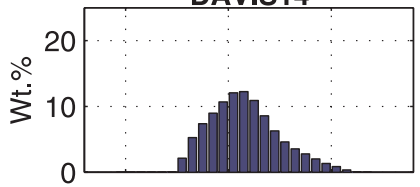

DAVIS12

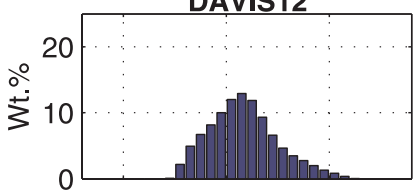

DAVIS11

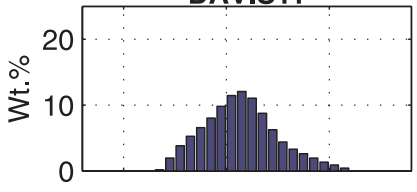

DAVIS10

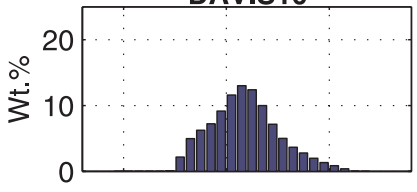

DAVIS7f

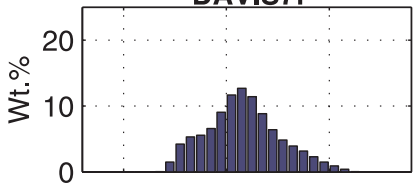

DAVIS1b

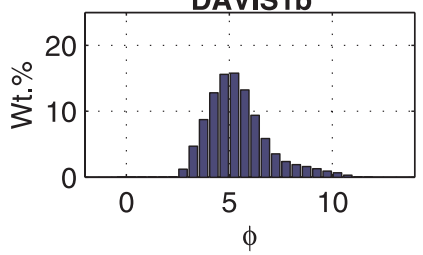

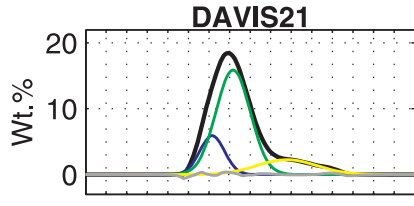

DAVIS17B

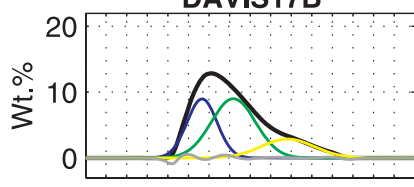

DAVIS14

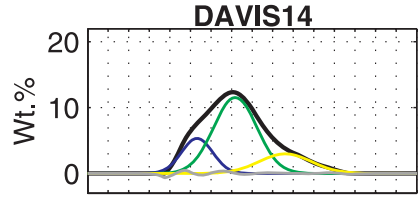

DAVIS12

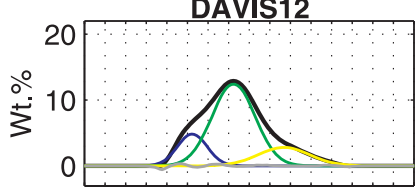

DAVIS11

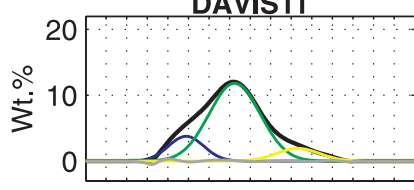

DAVIS10

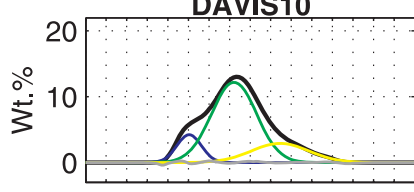

DAVIS7f

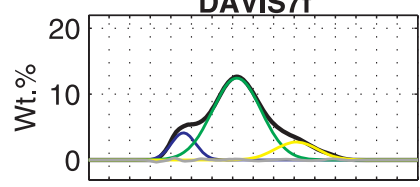

DAVIS1b

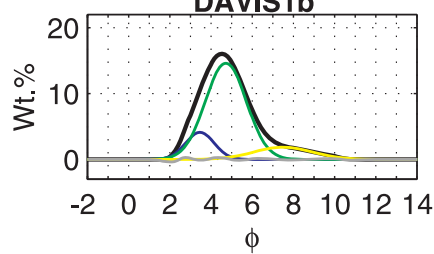

Figure 8. Particle size distributions of samples in Davis transect. Size distribution is shown in units of (left) $\mu \mathrm{m}$ and (middle) phi. (right) Lognormal subpopulations.

and particle sedimentation. Williams and McNutt [2004] report examples of both liquid and frozen hydrometeor fallout from volcanic clouds, and Sparks et al. [1997, pp. 438-444] describe examples of ash-hydrometeors observed during recent eruptions. Proximal MSH80 accretionary lapilli observed by Hoblitt et al. [1981] involved the condensation of water from various streams and rivers that were vaporized during the eruption. Waitt [1981] describes "dark gray pisolitic mud" that fell from a coignimbrite plume originating from the initial catastrophic landslide. Observers located approximately $15 \mathrm{~km}$ east of Mount St.
Helens reported fallout of "chunks of ice" and "ice-cold mudballs as much as 3.5 in. across" and water-rich accretionary lapilli were observed settling in the same area [Rosenbaum and Waitt, 1981]. Approximately $18 \mathrm{~km}$ to the north of the volcano, the first fallout to reach the ground was "cold and was like mud." Slightly farther north at $22 \mathrm{~km}$ from the volcano, "ash began falling in small clumps like snowflakes." There were numerous additional accounts of ash falling as moist "mudballs" in the region north of the volcano. 


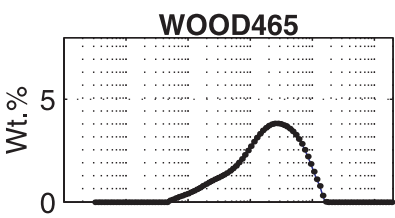

WOOD463.5

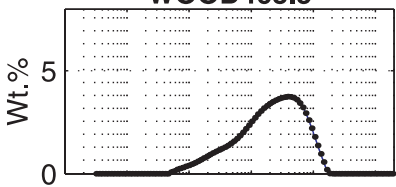

WOOD424.5

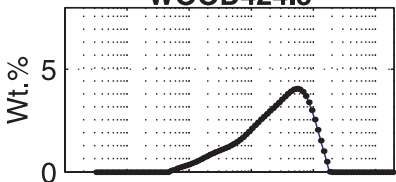

WOOD412

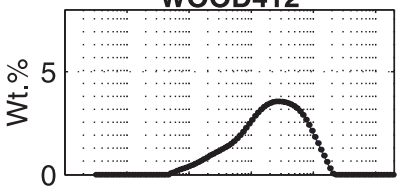

WOOD328

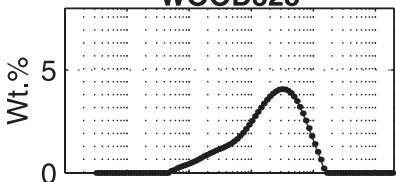

WOOD288E

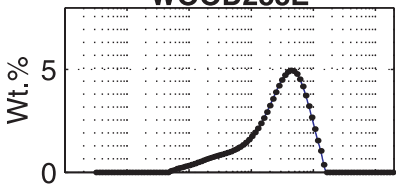

WOOD1

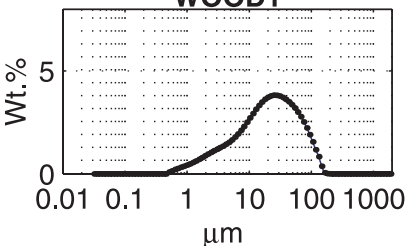

WOOD465

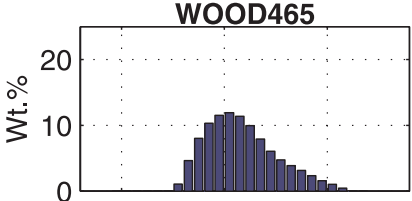

WOOD463.5

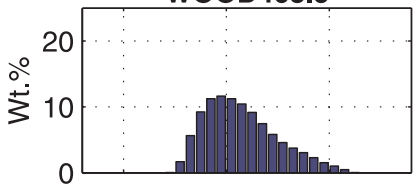

WOOD424.5

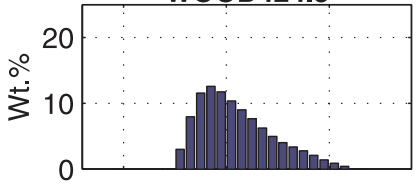

WOOD412

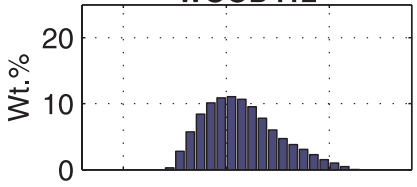

WOOD328

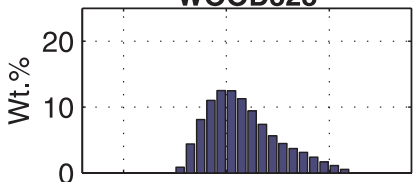

WOOD288E

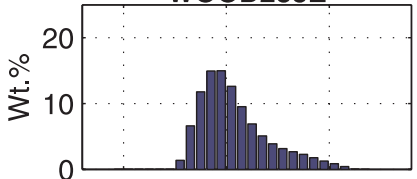

WOOD1

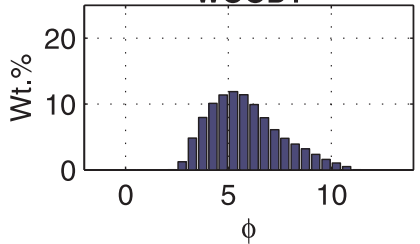

WOOD465

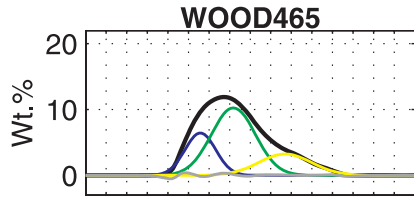

WOOD463.5

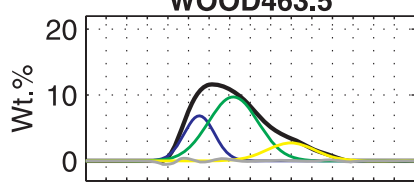

WOOD424.5

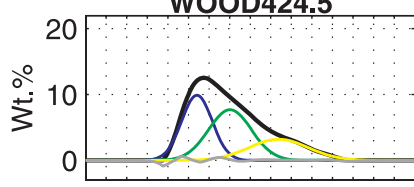

WOOD412

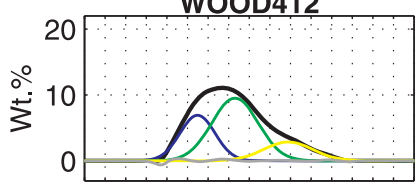

WOOD328

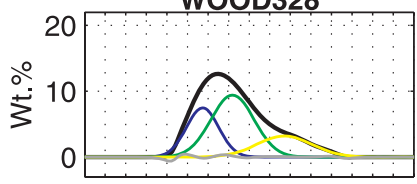

WOOD288E

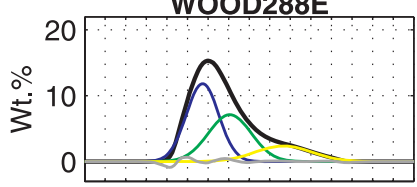

WOOD1

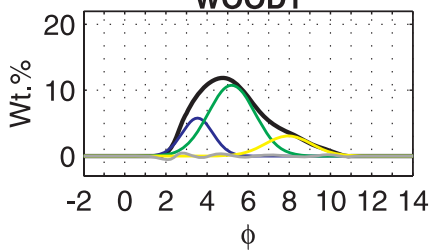

Figure 9. Particle size distributions of samples in Wood transect. Size distribution is shown in units of (left) $\mu \mathrm{m}$ and (middle) phi. (right) Lognormal subpopulations.

[30] Radar observations of the MSH80 cloud provide another source of evidence for hydrometeor involvement in both the aggregation mechanism and particle sedimentation. The MSH80 cloud was observed by meteorological radars based in Portland, Oregon, and Spokane and Seattle, Washington [Harris et al., 1981], and combined plan position indicator (PPI; fixed elevation angle) and range height indicator (RHI; fixed azimuth) observations to determine cloud area and height over time. Relative spatial variations in reflectivity were contoured according to predefined reference levels correlating to rainfall intensity equivalents: level 1, 18-30 dBZ (very light rain or snow); level 2, 30-38 dBZ (stratiform warm rain or snow); level 3, 38-44 dBZ; (moderate to heavy rain); level 4, 44-50 dBZ (heavy rain). For the majority of the observational period, the cloud had an associated level 1 reflectivity that originated at the volcano.

[31] A distal isolated region of radar reflectivity appeared $2-3 \mathrm{~h}$ after eruption at a location $\sim 300 \mathrm{~km}$ from the volcano and persisted downwind from the volcano for the following $\sim 11 \mathrm{~h}$. Between 1740 PDT and 1840 PDT, the intensity of the downwind reflectivity increased to level 2 (Figure 14), the same location as the secondary maximum in mass deposition at the ground. The radar observations of enhanced reflectivity at distance have two possible origins. First, radar reflectivity is proportional to the size of particles in the atmosphere so the increase in reflectivity at distance implies that particles in the cloud increased in size. This may be either a result of ash particle aggregation, growth of hydrometeors on ash particles, or a combination of both. Second, the enhanced reflectivity could result from the 


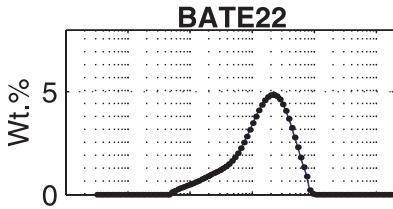

BATE17

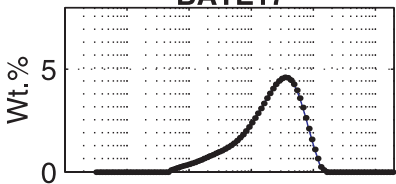

BATE12

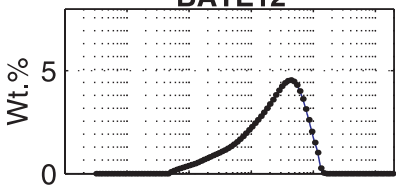

BATE7

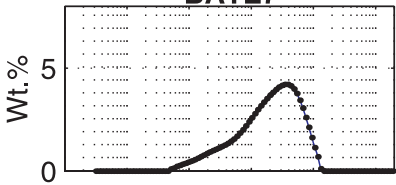

BATE24B

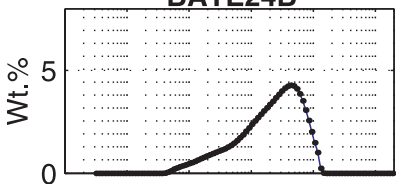

BATE29

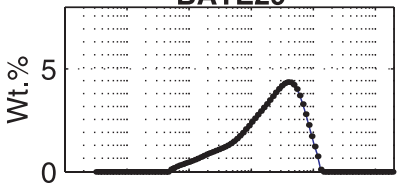

BATE34

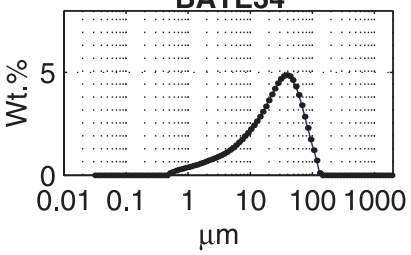

BATE22

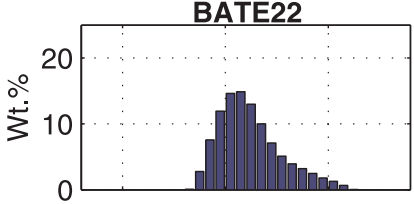

BATE17

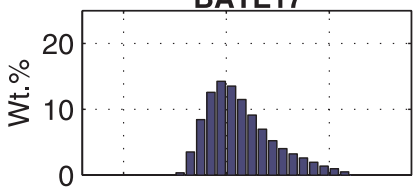

BATE12

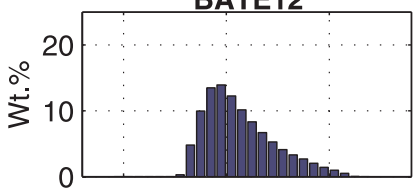

BATE7

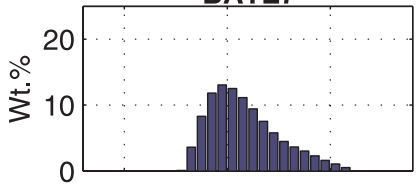

BATE24B

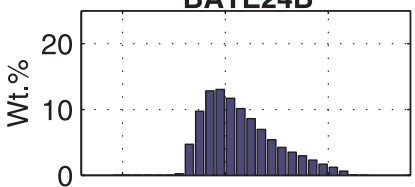

BATE29

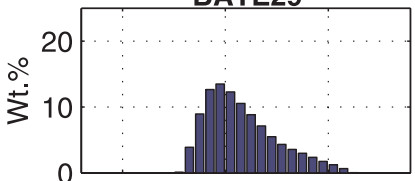

BATE34

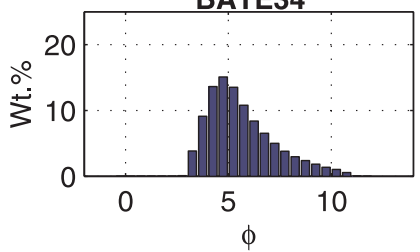

BATE22

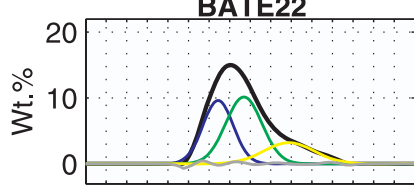

BATE17

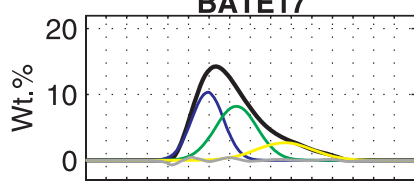

BATE12

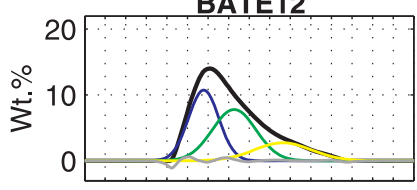

BATE7

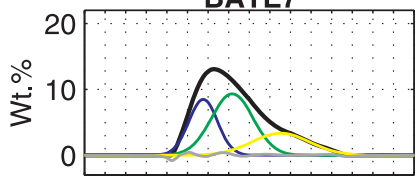

BATE24b

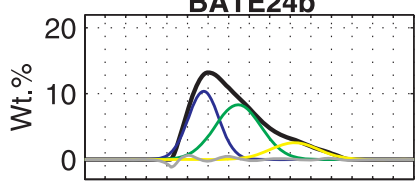

BATE29

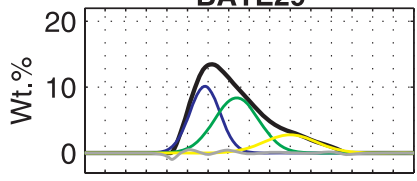

BATE34

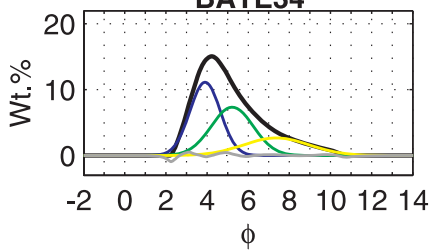

Figure 10. Particle size distributions of samples in Bate transect. Size distribution is shown in units of (left) $\mu \mathrm{m}$ and (middle) phi. (right) Lognormal subpopulations.

process that generates the radar "bright band" seen in vertical radar profiles, which occurs as frozen hydrometeors pass through the $0^{\circ} \mathrm{C}$ isotherm and form a cloud of mixed phase hydrometeors. Compared to raindrops, snowflakes have a complex morphology that results in high drag and lower fall velocities in the atmosphere. As a consequence, the volumetric mass loading of snowflakes in the atmosphere is greater than water drops, which have higher fall velocities and larger separation distances between hydrometeor particles. Enhanced reflectivity occurs as a snowflake enters the melting zone and the outside of the particle becomes liquid, while the mass loading, particle density and fall velocity do not change much. Liquid hydrometeors have a higher radar reflectivity than frozen hydrometeors because of greatly different dielectric properties. As the snowflake fully melts, the structure collapses and forms a drop, and fall velocity and separation distance between hydrometeor particles increases, which leads to a decrease in reflectivity. In the absence of quantitative information on radar beam azimuth from the radars observing the MSH80 eruption, it is not possible to apply the radar equation to constrain the height at which the distal reflectivity maximum was located. However, this could be tested at a future volcanic eruption using a modern radar system.

\subsection{Mammatus-Driven Fine Ash Sedimentation}

[32] Mammatus are pouch-like lobes that form on the underside of thunderstorm anvils in the waning stages of cumulonimbus evolution [Schultz et al., 2006]. Mammatus typically contain ice aggregates [Schultz et al., 2006] and are weakly turbulent with a descending core surrounded by a weaker circumferential updraft [e.g., Winstead et al., 

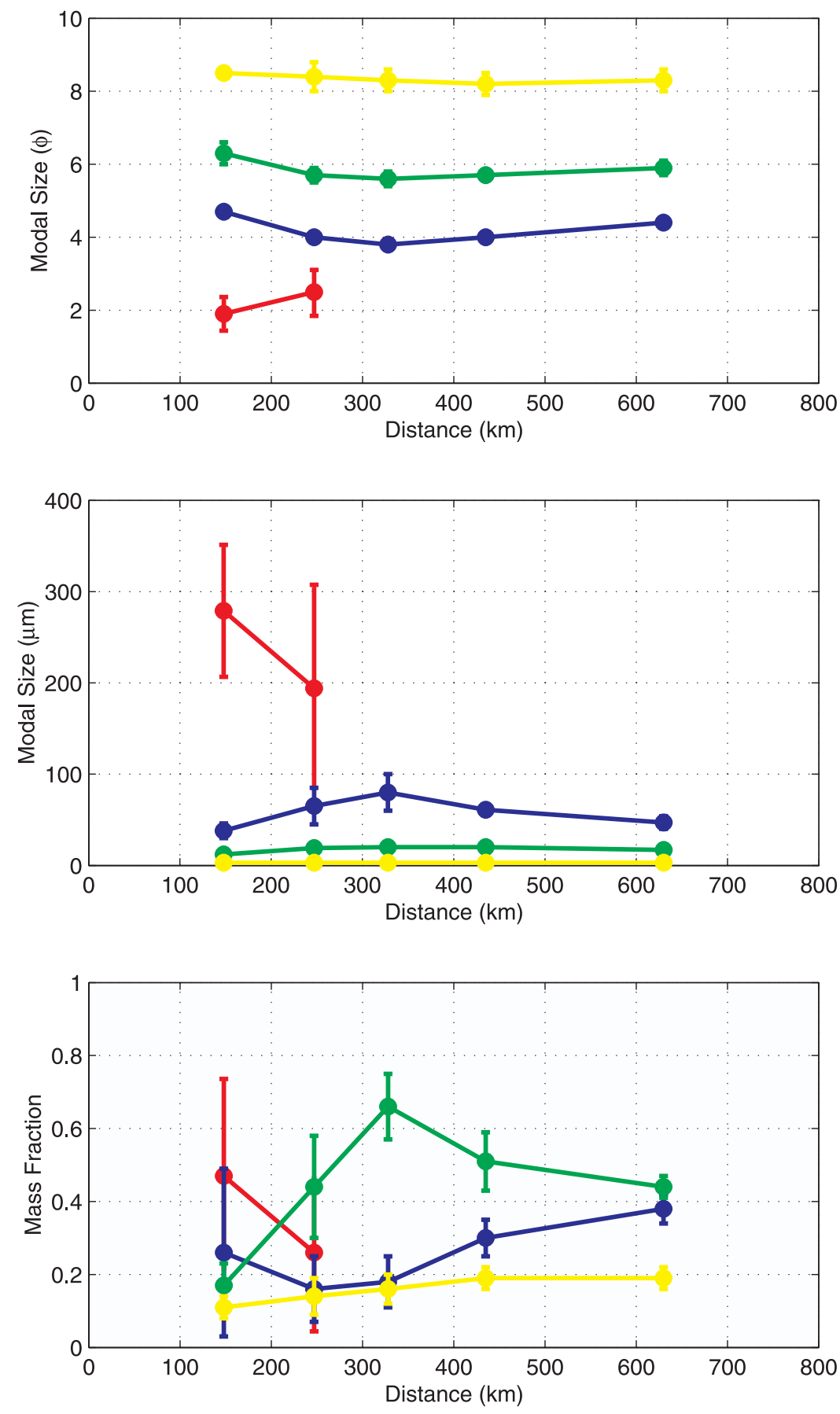

Figure 11. Particle subpopulations in MSH80 fallout averaged by transect as a function of distance from Mount St. Helens. Modes in units of (top) phi and (middle) $\mu \mathrm{m}$. Overall average modes are located at $2.2 \Phi(237 \mu \mathrm{m}), 4.2 \Phi(58 \mu \mathrm{m}), 5.8 \Phi(19 \mu \mathrm{m})$, and $8.3 \Phi(3 \mu \mathrm{m})$. (bottom) The proportion of each subpopulation as a function of distance. There is an enhancement in the proportion of the subpopulation with a mode at $5.8 \Phi(19 \mu \mathrm{m})$ over the distal mass deposition maximum.

2001]. Typical descent rates in the core of mammatus clouds are $3 \mathrm{~m} \mathrm{~s}^{-1}$ [Schultz et al., 2006], which is several orders of magnitude greater than terminal fall velocities of single particles in the cloud. Mammatus have been documented on many recent volcanic clouds (e.g., 27-31 March 1986 eruption of Mount St. Augustine, Alaska, and Mount Redoubt on 21 April 1990 [Schultz et al., 2006, 2008]) and were a commonly observed feature on the distal MSH80 volcanic cloud, e.g., at Ephrata, Washington, and Richland, Washington [Schultz et al., 2006, Figure 1h].

[33] Of the many proposed hypotheses to explain mammatus dynamics, three may be most relevant for volcanic cloud dynamics [Schultz et al., 2006; Kanak et al., 2008]: (1) ashhydrometeor evaporation/sublimation at the cloud base, (2) ash-hydrometeor fallout, and (3) cloud base detrainment instability (CDI). In the first mechanism, hydrometeors 
Table 7. Polymodal Analysis of MSH80 Fallout ${ }^{\mathrm{a}}$

\begin{tabular}{|c|c|c|c|c|c|}
\hline \multirow[b]{2}{*}{ Sample } & \multicolumn{4}{|c|}{ Subpopulation Mode $(\phi)$} & \multirow[b]{2}{*}{ Residual (\%) } \\
\hline & 1 & 2 & 3 & 4 & \\
\hline DZ20-32 & 1.4 & 4.3 & 6.4 & 8.4 & 2.48 \\
\hline DZ20-25 & 2.7 & 4.3 & 6.0 & 8.6 & 2.48 \\
\hline DZ20-21 & 2.1 & 5.1 & 6.4 & 8.5 & 3.47 \\
\hline DZ20-16 & 1.7 & 4.9 & 6.5 & 8.5 & 4.74 \\
\hline DZ20-6 & 1.5 & 5.3 & 7.4 & 9.1 & 5.35 \\
\hline DZ20-5 & 1.8 & 4.7 & 6.1 & 8.4 & 4.09 \\
\hline DZ20-3 & 1.9 & 4.7 & 6.2 & 8.5 & 5.16 \\
\hline Mean & 1.9 & 4.8 & 6.4 & 8.6 & \\
\hline SD & 0.4 & 0.4 & 0.5 & 0.2 & \\
\hline DZ21-3 & 1.2 & 3.7 & 5.4 & 9.0 & 2.02 \\
\hline DZ21-7 & 3.1 & 4.5 & 6.0 & 8.3 & 1.98 \\
\hline DZ21-8 & 2.5 & 4.7 & 6.0 & 8.1 & 2.39 \\
\hline DZ21-9 & 2.7 & 4.4 & 5.9 & 8.1 & 0.91 \\
\hline DZ21-11 & 2.6 & 3.6 & 5.6 & 7.9 & 2.92 \\
\hline DZ21-12 & 2.8 & 3.7 & 5.7 & 8.7 & 1.98 \\
\hline DZ21-14 & 2.7 & 3.5 & 5.6 & 8.3 & 2.98 \\
\hline Mean & 2.5 & 4.0 & 5.7 & 8.3 & \\
\hline SD & 0.6 & 0.5 & 0.2 & 0.4 & \\
\hline DAVIS21 & & 4.65 & 5.67 & 8.29 & 2.7 \\
\hline DAVIS17b & & 4.16 & 5.69 & 8.32 & 3.76 \\
\hline DAVIS14 & & 3.82 & 5.68 & 8.11 & 2.92 \\
\hline DAVIS12 & & 3.74 & 5.74 & 8.19 & 2.32 \\
\hline DAVIS11 & & 3.39 & 5.75 & 8.83 & 2.42 \\
\hline DAVIS10 & & 3.53 & 5.72 & 7.96 & 2.08 \\
\hline DAVIS7f & & 3.11 & 5.71 & 8.6 & 2.02 \\
\hline DAVIS1b & & 3.97 & 5.23 & 8.01 & 2.4 \\
\hline Mean & & 3.8 & 5.6 & 8.3 & \\
\hline SD & & 0.5 & 0.2 & 0.3 & \\
\hline WOOD463.5 & & 4.03 & 5.68 & 8.47 & 2.83 \\
\hline WOOD424.5 & & 3.91 & 5.52 & 7.88 & 3.49 \\
\hline WOOD412 & & 3.99 & 5.81 & 8.39 & 2.63 \\
\hline WOOD328 & & 4.23 & 5.69 & 8.21 & 2.99 \\
\hline Mean & & 4.0 & 5.7 & 8.2 & \\
\hline $\mathrm{SD}$ & & 0.1 & 0.1 & 0.3 & \\
\hline BATE22 & & 4.94 & 6.19 & 8.39 & 3.06 \\
\hline BATE17 & & 4.43 & 5.82 & 8.17 & 3.24 \\
\hline BATE12 & & 4.29 & 5.77 & 8.14 & 3.81 \\
\hline BATE7 & & 4.27 & 5.68 & 8.03 & 3.1 \\
\hline BATE24b & & 4.28 & 5.96 & 8.7 & 4.23 \\
\hline BATE29 & & 4.35 & 5.89 & 8.49 & 3.57 \\
\hline BATE34 & & 4.41 & 5.72 & 7.87 & 3.58 \\
\hline Mean & & 4.4 & 5.9 & 8.3 & \\
\hline $\mathrm{SD}$ & & 0.2 & 0.2 & 0.3 & \\
\hline $\begin{array}{l}\text { Mean for all } \\
\text { sample locations }\end{array}$ & 2.2 & 4.2 & 5.9 & 8.3 & \\
\hline $\begin{array}{l}\text { SD for all } \\
\text { sample locations }\end{array}$ & 0.5 & 0.3 & 0.2 & 0.3 & \\
\hline
\end{tabular}

${ }^{\mathrm{a}}$ In phi units.

(water drops or ice crystals) fall into dry air below the cloud and evaporate or sublimate. This process has an associated negative latent heat that results in localized cooling. The air at the base of the cloud then becomes denser and descends. In pure water mammatus, this mechanism is supported by measurements of hydrometeor size decreasing toward the base of mammatus lobes, a temperature inversion and the presence of a subcloud dry layer [Schultz et al., 2006]. In the second mechanism, particle loading leads to the forma- tion of a vertically descending region (precipitation shaft) that expands radially as a result of frictional drag around the edges. This formation mechanism shares analogies to sedimentation-driven convection instabilities that can lead to finger formation at a density interface and greatly enhanced particle settling relative to individual rates [e.g., Carey, 1997; Hoyal et al., 1999]. Hydrometeor aggregate formation and differential particle fallout rates resulting from a broadened size distribution may also contribute to mammatus

Table 8. Polymodal Analysis of MSH80 Fallout ${ }^{\mathrm{a}}$

\begin{tabular}{|c|c|c|c|c|c|}
\hline \multirow[b]{2}{*}{ Sample } & \multicolumn{4}{|c|}{ Subpopulation Mode (mm) } & \multirow[b]{2}{*}{ Residual (\%) } \\
\hline & 1 & 2 & 3 & 4 & \\
\hline DZ20-32 & 0.369 & 0.049 & 0.012 & 0.003 & 2.48 \\
\hline DZ20-25 & 0.153 & 0.049 & 0.015 & 0.003 & 2.48 \\
\hline DZ20-21 & 0.240 & 0.028 & 0.012 & 0.003 & 3.47 \\
\hline DZ20-16 & 0.301 & 0.034 & 0.011 & 0.003 & 4.74 \\
\hline DZ20-6 & 0.349 & 0.025 & 0.006 & 0.002 & 5.35 \\
\hline DZ20-5 & 0.291 & 0.038 & 0.015 & 0.003 & 4.09 \\
\hline DZ20-3 & 0.268 & 0.038 & 0.014 & 0.003 & 5.16 \\
\hline Mean & 0.281 & 0.037 & 0.012 & 0.003 & \\
\hline SD & 0.072 & 0.009 & 0.003 & 0.000 & \\
\hline DZ21-3 & 0.441 & 0.077 & 0.024 & 0.002 & 2.02 \\
\hline DZ21-7 & 0.115 & 0.045 & 0.016 & 0.003 & 1.98 \\
\hline DZ21-8 & 0.178 & 0.039 & 0.015 & 0.004 & 2.39 \\
\hline DZ21-9 & 0.150 & 0.047 & 0.017 & 0.004 & 0.91 \\
\hline DZ21-11 & 0.170 & 0.080 & 0.021 & 0.004 & 2.92 \\
\hline DZ21-12 & 0.149 & 0.079 & 0.019 & 0.002 & 1.98 \\
\hline DZ21-14 & 0.155 & 0.087 & 0.020 & 0.003 & 2.98 \\
\hline Mean & 0.194 & 0.065 & 0.019 & 0.003 & \\
\hline SD & 0.111 & 0.020 & 0.003 & 0.001 & \\
\hline DAVIS21 & & 0.040 & 0.020 & 0.003 & 2.7 \\
\hline DAVIS17b & & 0.056 & 0.019 & 0.003 & 3.76 \\
\hline DAVIS14 & & 0.071 & 0.020 & 0.004 & 2.92 \\
\hline DAVIS12 & & 0.075 & 0.019 & 0.003 & 2.32 \\
\hline DAVIS11 & & 0.095 & 0.019 & 0.002 & 2.42 \\
\hline DAVIS10 & & 0.087 & 0.019 & 0.004 & 2.08 \\
\hline DAVIS7f & & 0.116 & 0.019 & 0.003 & 2.02 \\
\hline DAVIS1b & & 0.064 & 0.027 & 0.004 & 2.4 \\
\hline Mean & & 0.080 & 0.020 & 0.003 & \\
\hline SD & & 0.020 & 0.003 & 0.001 & \\
\hline WOOD463.5 & & 0.061 & 0.020 & 0.003 & 2.83 \\
\hline WOOD424.5 & & 0.067 & 0.022 & 0.004 & 3.49 \\
\hline WOOD412 & & 0.063 & 0.018 & 0.003 & 2.63 \\
\hline WOOD328 & & 0.053 & 0.019 & 0.003 & 2.99 \\
\hline Mean & & 0.061 & 0.020 & 0.003 & \\
\hline SD & & 0.006 & 0.002 & 0.001 & \\
\hline BATE22 & & 0.033 & 0.014 & 0.003 & 3.06 \\
\hline BATE17 & & 0.046 & 0.018 & 0.003 & 3.24 \\
\hline BATE12 & & 0.051 & 0.018 & 0.004 & 3.81 \\
\hline BATE7 & & 0.052 & 0.020 & 0.004 & 3.1 \\
\hline BATE24b & & 0.051 & 0.016 & 0.002 & 4.23 \\
\hline BATE29 & & 0.049 & 0.017 & 0.003 & 3.57 \\
\hline BATE34 & & 0.047 & 0.019 & 0.004 & 3.58 \\
\hline Mean & & 0.047 & 0.017 & 0.003 & \\
\hline SD & & 0.007 & 0.002 & 0.001 & \\
\hline $\begin{array}{l}\text { Mean for all } \\
\text { sample locations }\end{array}$ & 0.233 & 0.058 & 0.018 & 0.003 & \\
\hline $\begin{array}{l}\text { SD for all } \\
\text { sample locations }\end{array}$ & 0.092 & 0.012 & 0.003 & 0.001 & \\
\hline
\end{tabular}

${ }^{\mathrm{a}}$ In mm units. 


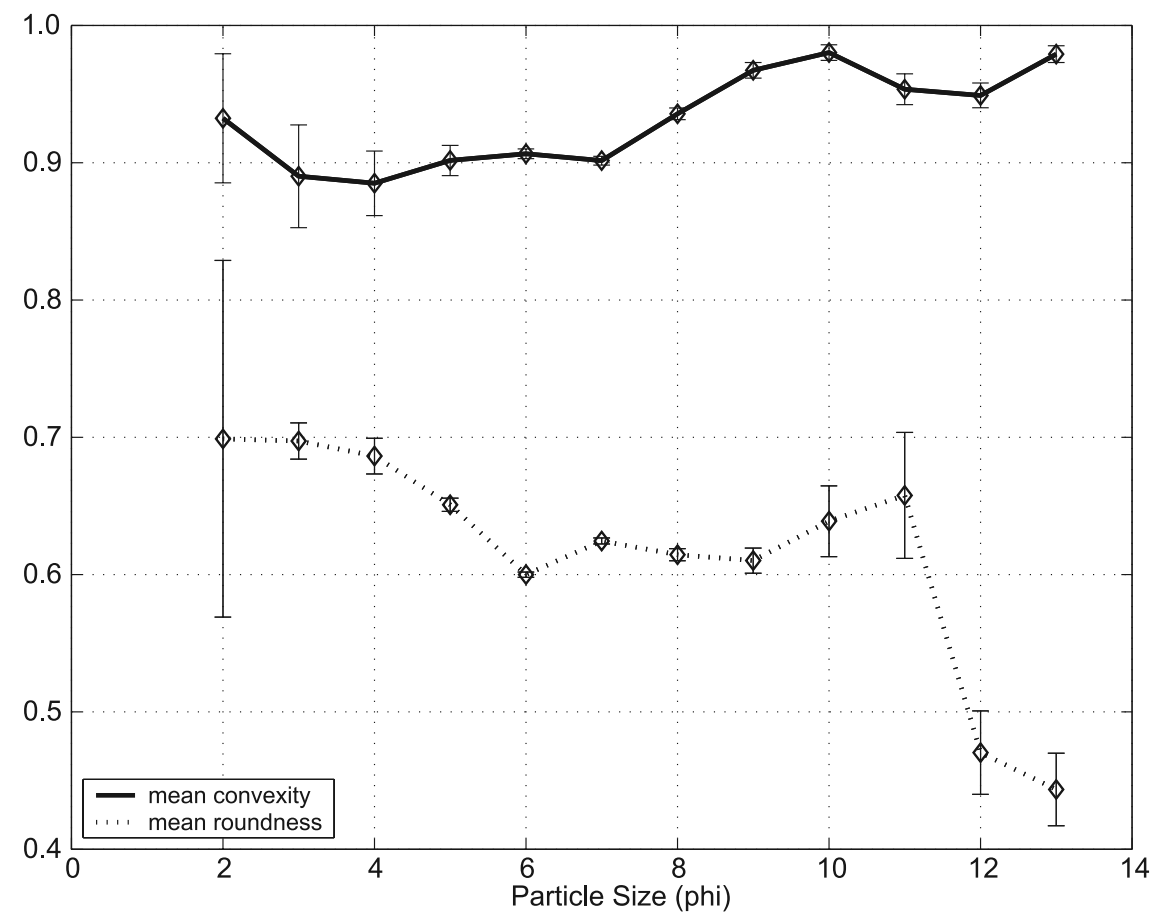

Figure 12. Particle shape analysis of MSH80 deposit dispersal axis samples. Curves show convexity and roundness as a function of phi size class.

lobe formation [Heymsfield, 1986]. In the third mechanism, cloudy air overlying dry clear air releases the resulting instability through mixing of moist air downward. In summary, mammatus formation requires sublimation and the CDI condition, and hydrometeor loading contributes but is not absolutely necessary for mammatus to form [Kanak et al., 2008].
[34] As most ash particles are effective ice-forming nuclei [Durant and Shaw, 2005; Shaw et al., 2005; Durant et al., 2008], volcanic mammatus will likely contain abundant iceencased ash particles. Particle aggregation is effective in pure water clouds down to temperatures between $-25^{\circ}$ to $-36^{\circ} \mathrm{C}$ [Heymsfield, 1986]. At warmer temperatures up to the melting point of ice, the aggregation rate rapidly

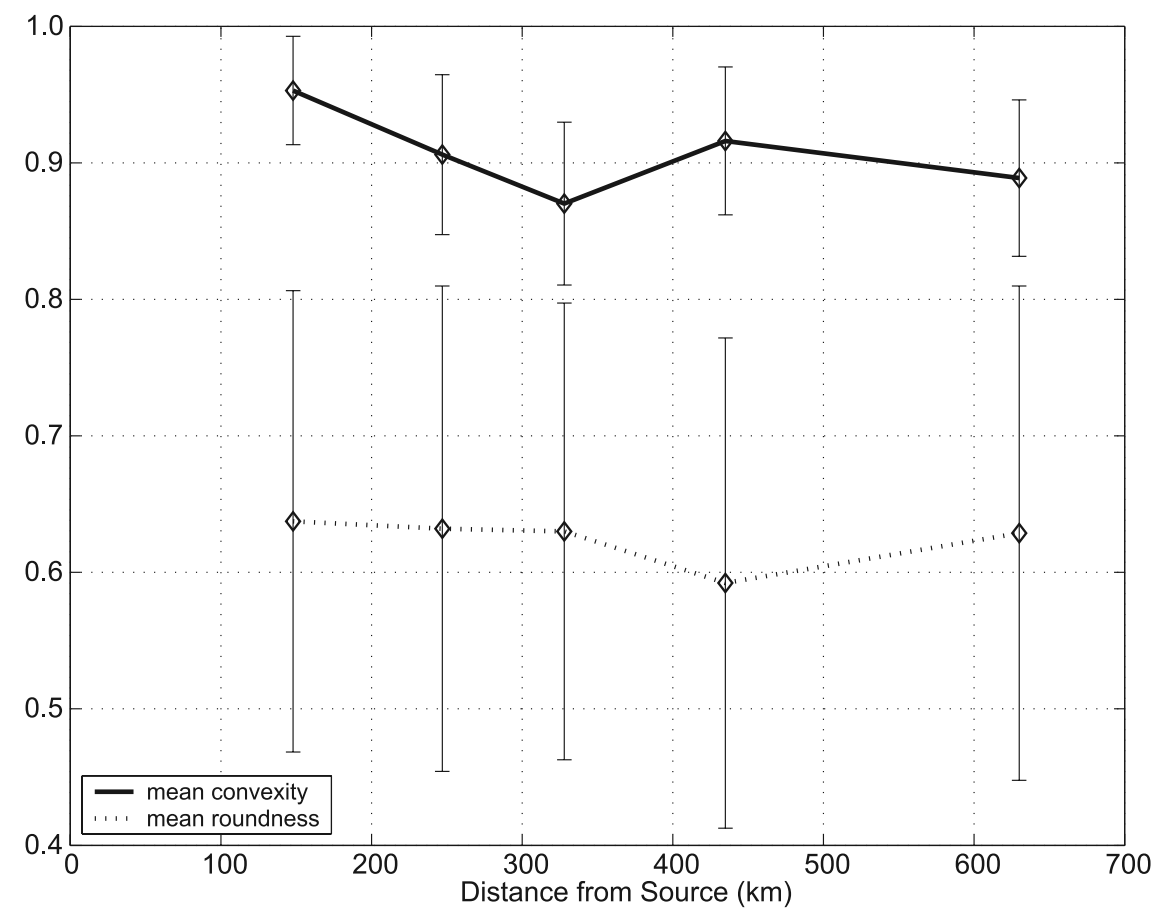

Figure 13. Particle shape analysis of MSH80 deposit dispersal axis samples. Curves show convexity and roundness as a function of distance from Mount St. Helens. 
CANADA

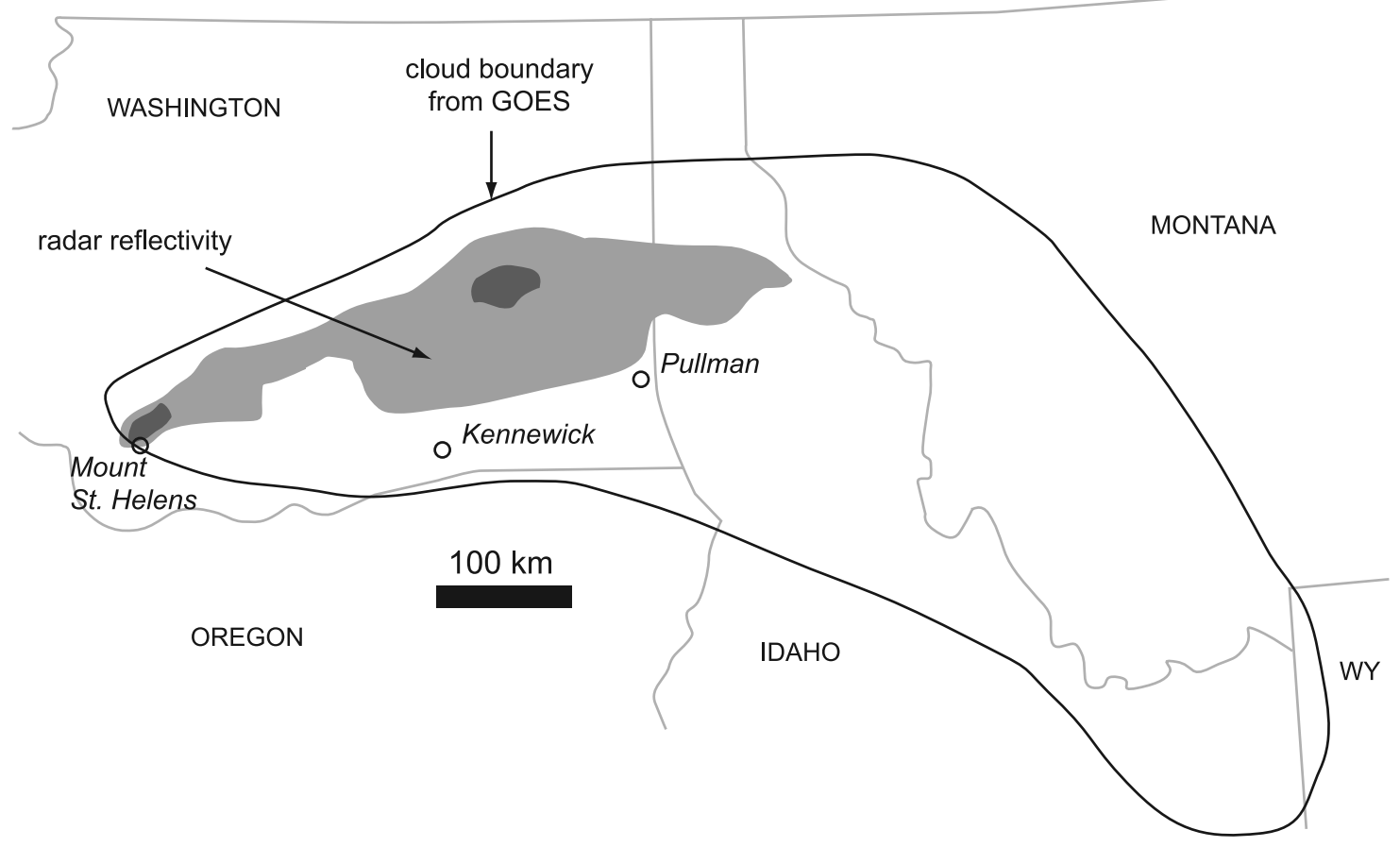

Figure 14. MSH80 cloud boundary determined from GOES-3 observations (solid black line) and meteorological radar reflectivity (gray shaded regions) at 1740 PDT (adapted from Harris et al. [1981]). Dark gray shading corresponds to level 2 reflectivity of Harris et al. [1981] which is equivalent to reflectivity of $30-38 \mathrm{dBZ}$. The light gray shading corresponds to a weaker reflectivity of $18-30 \mathrm{dBZ}$. The high reflectivities located about $300 \mathrm{~km}$ downwind indicate that particle size in the drifting cloud has increased markedly and/or that the cloud is passing through the $0^{\circ} \mathrm{C}$ isotherm.

increases [Pike, 1988; Lawson et al., 1998]. For example, large snowflake aggregates form in mixed phase clouds of supercooled liquid water droplets and ice, where turbulence enhances clustering and aggregation of cloud particles [Pike, 1988]. In a microphysics simulation by Kanak and Straka [2006], a cloud layer containing $10 \mu \mathrm{m}$ diameter ice crystals (terminal fall velocity of $\sim 10^{-3} \mathrm{~m} \mathrm{~s}^{-1}$ ) aggregated and formed mammatus-like lobes with a descent rate of $\sim 6.5 \mathrm{~m} \mathrm{~s}^{-1}$.

[35] Widespread ash aggregate fall and fine ash deposition was coincident with the presence of mammatus lobes on the MSH80 cloud. The proportion of subpopulation 3 (with a mode at $19 \mu \mathrm{m}$ at $330 \mathrm{~km}$ distance) is greatly enhanced in the ash deposit over this same region. Theoretical modeling of turbulence-induced collision and coagulation by R. A. Shaw and W. I. Rose (Evidence for turbulence-induced ash aggregation in volcanic clouds, unpublished manuscript, 2005) indicates that an ash particle distribution with a mode of $20 \mu \mathrm{m}$ is most susceptible to collisions resulting from inertial response in turbulent eddies (a similar study has been carried out for meteorological equivalents [Shaw, 2003]). This may result in preferential binding of particles with a size near $20 \mu \mathrm{m}$.

\subsection{Conceptual Model for Distal Volcanic Ash Particle Deposition}

[36] We now present a conceptual model for distal ash deposition that includes meteorological processes (Figure 15).

\subsubsection{Process 1: Ice Crystal Growth on Ash Particles}

[37] Ash particles in the eruption cloud nucleate ice, become encased and settle faster. Remote sensing has shown that ice is an integral component of volcanic clouds [e.g., Rose et al., 2004] and that ash particles are incorporated in hydrometeors [e.g., Rose et al., 1995; Guo et al., 2004; Lacasse et al., 2004].

\subsubsection{Processes 2 and 3: Mammatus Generation} and Rapid Cloud Subsidence

[38] Cloud base descends because of ash-hydrometeor loading, and evaporation/sublimation at the cloud base contributes to mammatus generation [Kanak et al., 2008]. These two processes are responsible for the cloud to descend at a rate greater than the majority of the terminal fall velocities of the individual particles.

\subsubsection{Process 4: Turbulence-Induced Aggregation}

[39] At temperatures warmer than $-36^{\circ} \mathrm{C}$, ash-hydrometeor aggregation can take place in a process analogous to snowflake production. This is supported by observations of snowflake formation [e.g., Heymsfield, 1986; Pike, 1988; Lawson et al., 1998] and theoretical modeling [Shaw, 2003].

5.3.4. Process 5: Mixed Phase Hydrometeors and Wet Aggregation

[40] As the cloud descends through the melting level (about $6.9 \mathrm{~km}$ on the day of the MSH80 eruption), ash-ice aggregates melt from the outside-in. The presence of mixed phase particles results in charge separation and electrostatic binding. The rate of aggregation increases rapidly in response to the availability of liquid water. 
(1) Ash particles nucleate ice, become encased, and settle faster

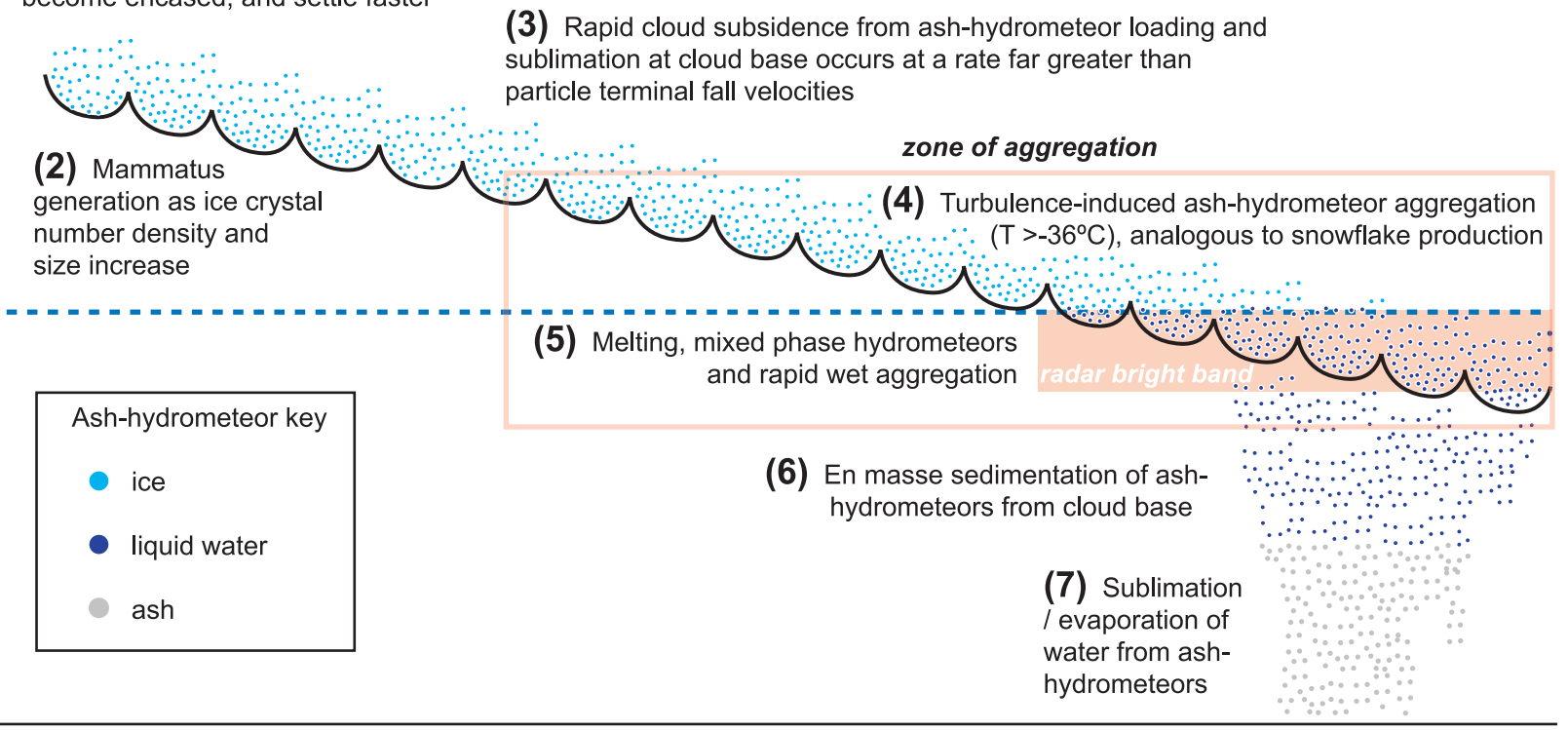

Figure 15. Model for mammatus-driven distal ash sedimentation, formation of aggregates, and distal mass deposition maxima in tephra deposits.

\subsubsection{Process 6: Rapid Ash-Hydrometeor Aggregate Fallout}

[41] Rapid growth of ash-hydrometeor aggregates through wet aggregation results in an instability and particles sediment en masse from the cloud base.

\subsubsection{Process 7: Evaporation/Sublimation of Water From Ash-Hydrometeors}

[42] During the final descent through the relatively dry middle troposphere, ash-hydrometeor aggregates lose water through sublimation and evaporation, leaving only weakly bound ash particle aggregates. Microscale films of water remain on ash particle surfaces and hold the aggregates together in addition to electrostatic forces.

\subsubsection{Process 8: Deposition of Ash Aggregates}

[43] Loosely bound ash aggregates reach the ground and form a secondary mass deposition maximum.

\section{Conclusions}

[44] We carried out an extensive sedimentological reanalysis of the MSH80 tephra deposit to understand how particle aggregation influences the formation of distal deposition maxima. We conclude the following:

[45] 1. Particle characteristics in the MSH80 deposit cannot be reconciled through simple modeling of terminal fall velocities of single particles found in the deposit. The majority of fallout $<100 \mu \mathrm{m}$ did not involve single-particle settling through the atmosphere. Fallout up to $300 \mathrm{~km}$ from the volcano involved single-particle fall (coarse particles $>100 \mu \mathrm{m})$ in addition to aggregate fall. The sedimentological characteristics of fallout beyond $>300 \mathrm{~km}$ was consistent and invariant, and particle removal was predominantly through the formation and fallout of aggregates.

[46] 2. Ash aggregation involves a particle subpopulation with a mode at $\sim 19 \mu \mathrm{m}$ and dispersion of $<8-31 \mu \mathrm{m}$.
Through identification of this signature, it should be possible to identify cases where ash aggregation enhanced sedimentation in historic or ancient eruptions.

[47] 3. Hydrometeor formation plays a fundamental role in volcanic cloud destabilization and sedimentation. Ash particles initiate hydrometeor formation, which results in particle loading at the cloud base. Ice growth on ash particles increases single-particle terminal fall velocities.

[48] 4. Large-scale subsidence of volcanic cloud layers occurs through mammatus cloud formation at a rate far greater than the terminal fall velocity of single particles.

[49] 5. Aggregation in distal portions of volcanic clouds occurs through a snowflake aggregation-like process. "Dry" aggregates are the remnants of ash-hydrometeors that have lost water through sublimation or evaporation.

[50] 6. Distal mass deposition maxima in tephra deposits form as a result of rapid aggregation and fallout as the cloud passes through the melting level in the atmosphere during descent.

[51] Acknowledgments. A.J.D. acknowledges support from the GREENCYCLES Marie Curie Research Training Network. David Schultz and two anonymous reviewers are thanked for thoughtful reviews that vastly improved an earlier version of this manuscript. Elmira Wan and the USGS Tephrochronology Laboratory (Menlo Park) are thanked for providing the MSH80 tephra samples and for assistance during a visit by A.J.D. in 2006. Ken Wohletz is thanked for helpful advice on the analysis of subpopulations in particle size data. Claire Horwell, Steve Boreham, and Chris Rolfe are acknowledged for assistance during the particle size analysis carried out at the University of Cambridge Physical Geography Laboratories Malvern Room facility. Kevin Trowbridge is thanked for hosting A.J.D. during a visit to San Francisco. Sebastien Dartevelle is thanked for helpful advice on the sedimentological analysis. Jeff Robel and the National Climatic Data Center are thanked for providing GOES imagery of the MSH80 eruption.

\section{References}

Armienti, P., G. Macedonio, and M. T. Pareschi (1988), A numerical model for simulation of tephra transport and deposition; applications to May 18 
1980, Mount St. Helens eruption, J. Geophys. Res., 93(B6), 6463-6476, doi:10.1029/JB093iB06p06463.

Blott, S. J., and K. Pye (2001), GRADISTAT: A grain size distribution and statistics package for the analysis of unconsolidated sediments, Earth Surf. Processes Landforms, 26, 1237-1248.

Bohren, C. F., and D. R. Huffman (1983), Absorption and Scattering of Light by Small Particles, 544 pp., John Wiley, Weinheim, Germany.

Bonadonna, C., G. G. J. Ernst, and R. S. J. Sparks (1998), Thickness variations and volume estimates of tephra fall deposits: The importance of particle Reynolds number, J. Volcanol. Geotherm. Res., 81(3-4), 173-187, doi:10.1016/S0377-0273(98)00007-9.

Bonadonna, C., G. Macedonio, and R. S. J. Sparks (2002), Numerical modeling of tephra fallout associated with dome collapses and Vulcanian explosions: Application to hazard assessment on Montserrat, in The Eruption of Soufrière Hills Volcano, Montserrat, From 1995 to 1999 , edited by T. H. Druitt and B. P. Kokelaar, Mem. Geol. Soc., 21, 517-537.

Bonadonna, C., A. C. Volentik, C. B. Connor, M. Rosi, and L. J. Connor (2006), Validation of sedimentation models: The case study of Pululagua Volcano, Ecuador, Eos Trans. $A G U, 87(52)$, Fall Meet. Suppl., Abstract V33B-0650.

Brazier, S., R. S. J. Sparks, S. N. Carey, H. Sigurdsson, and J. A. Westgate (1983), Bimodal grain size distribution and secondary thickening in airfall ash layers, Nature, 301(5896), 115-119, doi:10.1038/301115a0.

Brown, P. P., and D. F. Lawler (2003), Sphere drag and settling velocity revisited, J. Environ. Eng., 129(3), 222-231, doi:10.1061/(ASCE)07339372(2003)129:3(222).

Carey, S. (1997), Influence of convective sedimentation on the formation of widespread tephra fall layers in the deep sea, Geology, 25(9), 839-842, doi:10.1130/0091-7613(1997)025<0839:IOCSOT >2.3.CO;2.

Carey, S. N., and H. Sigurdsson (1982), Influence of particle aggregation on deposition of distal tephra from the May 18, 1980, eruption of Mount St. Helens volcano, J. Geophys. Res., 87(B8), 7061-7072, doi:10.1029/ JB087iB08p07061.

Carey, S., H. Sigurdsson, J. E. Gardner, and W. Criswell (1990), Variations in column height and magma discharge during the May 18, 1980 eruption of Mount St. Helens, J. Volcanol. Geotherm. Res., 43, 99-112, doi:10.1016/0377-0273(90)90047-J.

Clift, R., J. R. Grace, and M. E. Weber (1978), Bubbles, Drops and Particles, 380 pp., Academic, San Diego, Calif.

Criswell, C. W. (1987), Chronology and pyroclastic stratigraphy of the May 18, 1980, eruption of Mount St. Helens, Washington, J. Geophys. Res., 92(B10), 10,237-10,266, doi:10.1029/JB092iB10p10237.

Danielsen, E. F. (1981), Trajectories of the Mount St. Helens eruption plume, Science, 211(4484), 819-821, doi:10.1126/science.211.4484.819.

Dartevelle, S., G. G. J. Ernst, and A. Bernard (2002), Origin of the Mount Pinatubo climactic eruption cloud: Implications for volcanic hazards and atmospheric impacts, Geology, 30(7), 663-666, doi:10.1130/00917613(2002)030<0663:OOTMPC >2.0.CO;2.

Dellino, P., D. Mele, R. Bonasia, G. Braia, L. La Volpe, and R. Sulpizio (2005), The analysis of the influence of pumice shape on its terminal velocity, Geophys. Res. Lett., 32(21), L21306, doi:10.1029/ 2005GL023954.

Durant, A. J. (2007), On water in volcanic clouds, 242 pp., Ph.D. dissertation, Mich. Technol. Univ., Houghton.

Durant, A. J., and R. A. Shaw (2005), Evaporation freezing by contact nucleation inside-out, Geophys. Res. Lett., 32, L20814, doi:10.1029/ 2005GL024175.

Durant, A. J., R. A. Shaw, W. I. Rose, Y. Mi, and G. G. J. Ernst (2008), Ice nucleation and overseeding of ice in volcanic clouds, J. Geophys. Res., 113, D09206, doi:10.1029/2007JD009064.

Fruchter, J. S., et al. (1980), Mount St. Helens ash from the 18 May 1980 eruption: Chemical, physical, mineralogical, and biological properties, Science, 209(4461), 1116-1125, doi:10.1126/science.209.4461.1116.

Gilbert, J. S., S. J. Lane, R. S. J. Sparks, and T. J. Casadevall (1991), Particle aggregation controlled by electrical charge in volcanic plumes, 20 pp., U.S. Geol. Surv., Reston, Va.

Guo, S., W. I. Rose, G. J. S. Bluth, and I. M. Watson (2004), Particles in the great Pinatubo volcanic cloud of June 1991: The role of ice, Geochem. Geophys. Geosyst., 5, Q05003, doi:10.1029/2003GC000655.

Harris, D. M., W. I. Rose Jr., R. Roe, M. R. Thompson, P. W. Lipman, and D. R. Mullineaux (1981), Radar observations of ash eruptions, in The 1980 Eruptions of Mount St. Helens, Washington, edited by P. W. Lipman and D. R. Mullineaux, U.S. Geol. Surv. Prof. Pap., 1250, 323-333.

Heymsfield, A. (1986), Ice particle evolution in the anvil of a severe thunderstorm during CCOPE, J. Atmos. Sci., 43, 2463-2478, doi:10.1175/ 1520-0469(1986)043<2463:IPEITA >2.0.CO;2.

Hildreth, W., and R. E. Drake (1992), Volcan Quizapu, Chilean Andes, Bull. Volcanol., 54(2), 93-125, doi:10.1007/BF00278002.

Hobbs, P. V., J. P. Tuell, D. A. Hegg, L. F. Radke, and M. W. Eltgroth (1982), Particles and gases in the emissions from the 1980-1981 volcanic eruptions of Mt. St. Helens, J. Geophys. Res., 87(C12), 11,062-11,086, doi:10.1029/JC087iC13p11062.

Hoblitt, R. P., and R. S. Harmon (1993), Bimodal density distribution of cryptodome dacite from the 1980 eruption of Mount St. Helens, Washington, Bull. Volcanol., 55, 421-437, doi:10.1007/BF00302002.

Hoblitt, R. P., C. D. Miller, and J. W. Vallance (1981), Origin and stratigraphy of the deposit produced by the May 18 directed blast, in The 1980 Eruptions of Mount St. Helens, Washington, edited by P. W. Lipman and D. R. Mullineaux, U.S. Geol. Surv. Prof. Pap., 1250, 401-419.

Holasek, R. E., and S. Self (1995), GOES weather satellite observations and measurements of the May 18, 1980, Mount St. Helens eruption, J. Geophys. Res., 100(B5), 8469-8487, doi:10.1029/94JB03137.

Hooper, P. R., I. W. Herrick, E. R. Laskowski, and C. R. Knowles (1980), Composition of the Mount St. Helens ashfall in the Moscow-Pullman area on 18 May 1980, Science, 209(4461), 1125-1126, doi:10.1126/ science.209.4461.1125

Horwell, C. J., R. S. J. Sparks, T. S. Brewer, E. W. Llewellin, and B. J. Williamson (2003), Characterization of respirable volcanic ash from the Soufriere Hills Volcano, Montserrat, with implications for human health hazards, Bull. Volcanol., 65(5), 346-362, doi:10.1007/s00445002-0266-6.

Hoyal, D., M. I. Bursik, and J. F. Atkinson (1999), Settling-driven convection: A mechanism of sedimentation from stratified fluids, J. Geophys. Res., Oceans, 104(C4), 7953-7966, doi:10.1029/1998JC900065.

James, M. R., S. J. Lane, and J. S. Gilbert (2000), Volcanic plume electrification; experimental investigation of a fracture-charging mechanism, J. Geophys. Res., 105(B7), 16,641-16,649, doi:10.1029/2000JB900068.

James, M. R., J. S. Gilbert, and S. J. Lane (2002), Experimental investigation of volcanic particle aggregation in the absence of a liquid phase, J. Geophys. Res., 107(B9), 2191, doi:10.1029/2001JB000950.

James, M. R., S. J. Lane, and J. S. Gilbert (2003), Density, construction, and drag coefficient of electrostatic volcanic ash aggregates, J. Geophys. Res., 108(B9), 2435, doi:10.1029/2002JB002011.

Kanak, K. M., and J. M. Straka (2006), An idealized numerical simulation of mammatus-like clouds, Atmos. Sci. Lett., 7(1), 2-8, doi:10.1002/ asl.121

Kanak, K. M., J. M. Straka, and D. M. Schultz (2008), Numerical simulation of mammatus, J. Atmos. Sci., 65(5), 1606-1621, doi:10.1175/ 2007JAS2469.1.

Kunii, D., and O. Levenspiel (1969), Fluidization Engineering, John Wiley, New York.

Lacasse, C., S. Karlsdóttir, G. Larsen, H. Soosalu, W. I. Rose, and G. G. J. Ernst (2004), Weather radar observations of the Hekla 2000 eruption cloud, Iceland, Bull. Volcanol., 66(5), 457-473, doi:10.1007/s00445003-0329-3.

Lawson, R. P., R. E. Stewart, and L. J. Angus (1998), Observations and numerical simulations of the origin and development of very large snowflakes, J. Atmos. Sci., 55, 3209-3229, doi:10.1175/1520-0469(1998)055< 3209:OANSOT $>2.0 . \mathrm{CO} ; 2$

Mather, T. A., and R. G. Harrison (2006), Electrification of volcanic plumes, Surv. Geophys., 27, 387-432, doi:10.1007/s10712-006-9007-2.

McGimsey, R. G., C. A. Neal, and C. M. Riley (2002), Areal distribution, thickness, mass, volume, and grain size of tephra-fall deposits from the 1992 eruptions of Crater Peak Vent, Mt. Spurr volcano, Alaska, U.S. Geol. Surv. Open File Rep., 01-370, 38 pp.

Miura, T., T. Koyaguchi, and Y. Tanaka (2002), Measurements of electric charge distribution in volcanic plumes at Sakurajima Volcano, Japan, Bull. Volcanol., 64(2), 75-93, doi:10.1007/s00445-001-0182-1.

Moore, J. G., and C. J. Rice (1984), Chronology and character of the May 18, 1980, explosive eruptions of Mount St. Helens, in Explosive Volcanism. Inception, Evolution, and Hazards, edited by F. R. Boyd, pp. 133-142, Natl. Acad. Press, Washington, D. C.

Murcray, D. G., F. J. Murcray, and B. B. Barker (1981), Changes in stratospheric water vapor associated with the Mount St. Helens eruption, Science, 211, 823-824, doi:10.1126/science.211.4484.823.

Pallister, J. S., R. P. Hoblitt, D. R. Crandell, D. R. Mullineaux, and S. Mount (1992), Helens a decade after the 1980 eruptions: Magmatic models, chemical cycles, and a revised hazards assessment, Bull. Volcanol., 54(2), 126-146, doi:10.1007/BF00278003.

Pike, W. S. (1988), Unusually Large Snowflakes, J. Meteorol., 13, 3-16. Pyle, D. M. (1989), The thickness, volume and grain size of tephra fall deposits, Bull. Volcanol., 51(1), 1-15, doi:10.1007/BF01086757.

Rice, C. J. (1981), Satellite observations of the Mt. St. Helens eruption of 18 May 1980, technical report, 32 pp., Aerosp. Corp., Space Sci. Lab., El Segundo Calif.

Riley, C. M., W. I. Rose, and G. J. S. Bluth (2003), Quantitative shape measurements of distal volcanic ash, J. Geophys. Res., 108(B10), 2504, doi:10.1029/2001JB000818.

Rogers, R. R., and M. K. Yau (1989), Short Course in Cloud Physics, 3rd ed., Pergamon, Oxford, U.K. 
Rose, W. I., and M. F. Hoffman (1980), The May 18, 1980 eruption of Mount St. Helens: The nature of the eruption with an atmospheric perspective, in Atmospheric Effects and Potential Climatic Impact of the 1980 Eruption of Mount St. Helens, NASA Conf. Publ., CP-2240.

Rose, W. I., D. M. Harris, G. Heiken, A. Sarna-Wojcicki, and S. Self (1982), Volcanological description of the 18 May 1980 eruption of Mount St. Helens, in Mount St. Helens Eruptions of 1980: Atmospheric Effects and Potential Climatic Impact, edited by R. E. Newell and A. Deepak, NASA Spec. Publ., SP 458, pp. 1-36.

Rose, W. I., R. L. Wunderman, M. F. Hoffman, and L. Gale (1983), A volcanologist's review of atmospheric hazards of volcanic activity: Fuego and Mount St Helens, J. Volcanol. Geotherm. Res., 17(1-4), 133-157, doi:10.1016/0377-0273(83)90065-3.

Rose, W. I., D. J. Delene, D. J. Schnelder, G. J. S. Bluth, A. J. Krueger, I. Sprod, C. McKee, H. L. Davies, and G. G. J. Ernst (1995), Ice in the 1994 Rabaul eruption cloud-Implications for volcano hazard and atmospheric effects, Nature, 375(6531), 477-479, doi:10.1038/375477a0.

Rose, W. I., C. M. Riley, L. J. Henderson, R. G. McGimsey, G. J. S. Bluth, D. J. Schneider, and G. G. J. Ernst (2001), Observations of volcanic clouds in their first few days of atmospheric residence: The 1992 eruptions of Crater Peak, Mount Spurr Volcano, Alaska, J. Geol., 109(6), 677-694, doi:10.1086/323189.

Rose, W. I., C. M. Riley, and S. Dartevelle (2003), Sizes and shapes of 10-Ma distal fall pyroclasts in the Ogallala Group, Nebraska, J. Geol., 111(1), 115-124, doi:10.1086/344668.

Rose, W. I., G. J. S. Bluth, and I. M. Watson (2004), Ice in volcanic clouds: When and where?, paper presented at the 2nd International Conference on Volcanic Ash and Aviation Safety, Off. of the Fed. Coord. for Meteorol., Washington, D.C

Rosenbaum, J. G., and R. B. Waitt (1981), Summary of eyewitness accounts of the May 18 eruptions, in The 1980 Eruptions of Mount St. Helens, Washington, edited by P. W. Lipman and D. R. Mullineaux, U.S. Geol. Surv. Prof. Pap., 1250, 53-67.

Sarna-Wojcicki, A. M., S. Shipley, R. B. Waitt Jr., D. Dzurisin, S. H. Wood, P. W. Lipman, and D. R. Mullineaux (1981), Areal distribution, thickness, mass, volume, and grain size of air-fall ash from the six major eruptions of 1980, in The 1980 Eruptions of Mount St. Helens, Washington, edited by P. W. Lipman and D. R. Mullineaux, U.S. Geol. Surv. Prof. Pap., $1250,577-600$

Scasso, R. A., H. Corbella, and P. Tiberi (1994), Sedimentological analysis of the tephra from the 12-15 August 1991 eruption of Hudson Volcano, Bull. Volcanol., 56(2), 121-132.

Schultz, D. M., et al. (2006), The mysteries of mammatus clouds: Observations and formation mechanisms, J. Atmos. Sci., 63(10), 2409-2435, doi:10.1175/JAS3758.1.

Schultz, D. M., A. J. Durant, J. M. Straka, and T. J. Garrett (2008), Reply, J. Atmos. Sci., 65(3), 1095-1097, doi:10.1175/2007JAS2544.1.

Schumacher, R. (1994), A reappraisal of Mount St. Helens's ash clusters: Depositional model from experimental observation, J. Volcanol. Geotherm. Res., 59(3), 253-260, doi:10.1016/0377-0273(94)90099-X.

Shaw, R. A. (2003), Particle-turbulence interactions in atmospheric clouds, Annu. Rev. Fluid Mech., 35, 183-227, doi:10.1146/annurev.fluid. 35.101101.161125.

Shaw, R. A., A. J. Durant, and Y. Mi (2005), Heterogeneous surface crystallization observed in undercooled water, J. Phys. Chem. B, 109, $9865-$ 9868, doi:10.1021/jp0506336.

Sorem, R. K. (1982), Volcanic ash clusters; tephra rafts and scavengers, J. Volcanol. Geotherm. Res., 13(1-2), 63-71, doi:10.1016/03770273(82)90019-1.

Sparks, R. S. J., J. G. Moore, and C. J. Rice (1986), The initial giant umbrella cloud of the May 18th, 1980, explosive eruption of Mount St.
Helens, J. Volcanol. Geotherm. Res., 28(3-4), 257-274, doi:10.1016/ 0377-0273(86)90026-0.

Sparks, R. S. J., M. I. Bursik, S. N. Carey, J. S. Gilbert, L. S. Glaze, H. Sigurdsson, and A. W. Woods (1997), Volcanic Plumes, 574 pp., John Wiley, Chichester, U.K.

Suzuki, T. (1983), A theoretical model for dispersion of tephra, in Arc Volcanism, Physics and Tectonics, edited by D. Shimozuru and I. Yokoyama, pp. 95-113, Terra Sci., Tokyo.

Volentik, A. C., C. Bonadonna, and C. Connor (2006), Characterization of grain size distribution and grain shape analysis of tephra deposits: A new approach based on automated microscopy and image analysis techniques, Eos Trans. $A G U, 87(52)$, Fall Meet. Suppl., Abstract V33B-0651.

Waitt, R. B. (1981), Devastating pyroclastic density flow and attendant air fall of May 18 - Stratigraphy and sedimentology of deposits, in The 1980 Eruptions of Mount St. Helens, Washington, edited by P. W. Lipman and D. R. Mullineaux, U.S. Geol. Surv. Prof. Pap., 1250, 439-458.

Waitt, R. B., and D. Dzurisin (1981), Proximal air-fall deposits from the May 18 eruption - stratigraphy and field sedimentology, in The 1980 Eruptions of Mount St. Helens, Washington, edited by P. W. Lipman and D. R. Mullineaux, U.S. Geol. Surv. Prof. Pap., 1250, 601-616.

Walker, G. P. L. (1971), Grain-size characteristics of pyroclastic deposits, J. Geol., 79, 696-714.

Walker, G. P. L. (1972), Crystal concentration in ignimbrites, Contrib. Mineral. Petrol., 36(2), 135-146, doi:10.1007/BF00371184.

Wiesner, M. G., A. Wetzel, S. G. Catane, E. L. Listanco, and H. T. Mirabueno (2004), Grain size, areal thickness distribution and controls on sedimentation of the 1991 Mt. Pinatubo tephra layer in the South China Sea, Bull. Volcanol., 66(3), 226-242, doi:10.1007/s00445-003-0306-x.

Williams, E. R. (1995), Comment on "Thunderstorm electrification laboratory experiments and charging mechanisms" by C.P.R. Saunders, J. Geophys. Res., 100(D1), 1503-1505, doi:10.1029/94JD01103.

Williams, E. R., and S. R. McNutt (2004), Total water contents in volcanic eruption clouds and implications for electrification and lightning, paper presented at the 2nd International Conference on Volcanic Ash and Aviation Safety, Off. of the Fed. Coord. for Meteorol., Washington, D.C.

Wilson, L., and T. C. Huang (1979), The influence of shape on the atmospheric settling velocity of volcanic ash particles, Earth Planet. Sci. Lett. 44, 311-324, doi:10.1016/0012-821X(79)90179-1.

Winstead, N. S., J. Verlinde, S. T. Arthur, F. Jaskiewicz, M. Jensen, N. Miles, and D. Nicosia (2001), High-resolution airborne radar observations of mammatus, Mon. Weather Rev., 129(1), 159-166, doi:10.1175/1520 0493(2001)129<0159:HRAROO>2.0.CO;2

Wohletz, K. H., M. F. Sheridan, and W. K. Brown (1989), Particle size distributions and the sequential fragmentation/transport theory applied to volcanic ash, J. Geophys. Res., 94(B11), 15,703-15,721, doi:10.1029/ JB094iB11p15703.

S. Carey, Graduate School of Oceanography, University of Rhode Island, Narragansett, RI 02882, USA.

A. J. Durant, Leverhulme Centre for Human Evolutionary Studies, University of Cambridge, Fitzwilliam Street, Cambridge CB2 1QH, UK. (ajdurant@mtu.edu)

W. I. Rose, Department of Geological and Mining Engineering and Sciences, Michigan Technological University, 1400 Townsend Drive, Houghton, MI 49931, USA.

A. M. Sarna-Wojcicki, U.S. Geological Survey, 345 Middlefield Road, MS 975, Menlo Park, CA 94025, USA.

A. C. M. Volentik, Department of Geology, University of South Florida, 4202 E. Fowler Avenue, Tampa, FL 33620, USA. 